\title{
Vertebrate Genome Evolution in the Light of Fish Cytogenomics and rDNAomics
}

\author{
Radka Symonová ${ }^{1, *(\mathbb{D})}$ and W. Mike Howell ${ }^{2}$ \\ 1 Faculty of Science, Department of Biology, University of Hradec Králové, 50003 Hradec Králové, \\ Czech Republic \\ 2 Department of Biological and Environmental Sciences, Samford University, Birmingham, AL 35229, USA; \\ wmhowell@samford.edu \\ * Correspondence: radka.symonova@gmail.com; Tel.: +420-776-121-054
}

Received: 30 November 2017; Accepted: 29 January 2018; Published: 14 February 2018

\begin{abstract}
To understand the cytogenomic evolution of vertebrates, we must first unravel the complex genomes of fishes, which were the first vertebrates to evolve and were ancestors to all other vertebrates. We must not forget the immense time span during which the fish genomes had to evolve. Fish cytogenomics is endowed with unique features which offer irreplaceable insights into the evolution of the vertebrate genome. Due to the general DNA base compositional homogeneity of fish genomes, fish cytogenomics is largely based on mapping DNA repeats that still represent serious obstacles in genome sequencing and assembling, even in model species. Localization of repeats on chromosomes of hundreds of fish species and populations originating from diversified environments have revealed the biological importance of this genomic fraction. Ribosomal genes (rDNA) belong to the most informative repeats and in fish, they are subject to a more relaxed regulation than in higher vertebrates. This can result in formation of a literal 'rDNAome' consisting of more than 20,000 copies with their high proportion employed in extra-coding functions. Because rDNA has high rates of transcription and recombination, it contributes to genome diversification and can form reproductive barrier. Our overall knowledge of fish cytogenomics grows rapidly by a continuously increasing number of fish genomes sequenced and by use of novel sequencing methods improving genome assembly. The recently revealed exceptional compositional heterogeneity in an ancient fish lineage (gars) sheds new light on the compositional genome evolution in vertebrates generally. We highlight the power of synergy of cytogenetics and genomics in fish cytogenomics, its potential to understand the complexity of genome evolution in vertebrates, which is also linked to clinical applications and the chromosomal backgrounds of speciation. We also summarize the current knowledge on fish cytogenomics and outline its main future avenues.
\end{abstract}

Keywords: fish cytogenomics; repetitive sequences; rDNAome; genome evolution; AT/GC compositional evolution; quantitative cytogenomics.

\section{Introduction}

\subsection{Introduction into Cytogenomics}

Cytogenomics, i.e., an integration of cytogenetic and genomic data and approaches supported by bioinformatics, is traditionally well established in clinical areas, particularly in cancer research and diagnostics [1,2]. Recently, cytogenomics has gained in importance in veterinary, e.g., [3] and in plant "-omics" research [4]. Along with progress in genomics, there was a literal call for "integrated cytogenomics" [5] in the recent endeavor towards the third-generation genome assemblies in avian genomics. In fish genome research, the first steps have already been taken [6-8]. Fish cytogenomics 
has been mentioned as the future pathway along which traditional fish cytogenetics should move [9] and is the logical outcome of the current integrating of fish biology research.

What can this synergy between cytogenetics and genomics offer in groups of fishes with less explored and non-model genomes? What is the potential of cytogenomics in fish with their sometimes very large genomes consisting of numerous small chromosomes stuffed with repetitive sequences? What is the status quo and what might or what should be the future of fish cytogenomics? Do we at all need any cytogenomic research of basal vertebrates so different from mammals and we humans? Is there any potential practical use of detailed knowledge on fish genomes? We definitely sense a strong need for fish cytogenomics to develop and unfold itself further and to help us to understand the intricate fish genome evolution. Moreover, we also need fish cytogenomics to gain insights into the evolution of other vertebrate genomes, not only because all other vertebrates originate from a fish-like ancestor. Hence, fish genomes should be viewed as the first stage towards the even higher structural and functional complexity of avian and mammalian genomes. However, fish genomes are far less explored (particularly regarding their diversity), the novel methods are applied with a delay in fishes and therefore, there is lot of work to do to compensate this delay. Fish represent a diversified spectrum of ways of genome organization (Table 1) and mirror the complex genome evolution of all tetrapod vertebrates (Tetrapodomorpha) embedded within Sarcopterygian fishes, the sister branch of Actinopterygian fishes [10].

\subsection{How Can This Review Been Utilized?}

The goal of this review is to summarize existing data and approaches usable in downstream analyses of the genomic makeup of fishes and other vertebrates and to integrate them in contexts enabling a comprehensive understanding of the evolution of vertebrate genomes. In this way, we aim to provide a solid baseline for future fish as well as vertebrate cytogenomic evolution research showing the importance and advantages of work on fish chromosomes and genomes. This shall assist cytogeneticists to effectively utilize genomics resources. We outline the crucial and inevitable directions of fish cytogenetics and genomics as both fields of study move toward the new integrative cytogenomics with their databases growing daily. We also delineate and highlight the importance of the shift from the qualitative karyology and cytogenetics to the quantitative evolutionary-ecological and environmental cytogenomics. Hence, we have to start viewing the cytogenomic results in a broader, evolutionary and phylogenomic context and linking cytogenomic phenomena with their corresponding ecological and physiological causes and consequences. This review shall further serve as a reference to non-fish vertebrate genome researchers, where however, fishes are necessarily included as the most basal vertebrates representing the starting point of the vertebrate's genome evolution. Finally, we present datasets of sequenced fish species listing their essential cytogenomic traits and information with potential for down-stream cytogenomic research and potential pitfalls and discrepancies to be regarded.

\subsection{The Complex Evolution of Vertebrates Began with Fish}

Understanding at least a basic framework and timescales of fish history substantially helps global understanding genome evolution in vertebrates. Jawless fishes as the first vertebrates with true bones arose in the early Paleozoic Era some 485 million years ago (mya). This crucial stage of our evolution remained conserved in lampreys and hagfishes that both considerably differ in their cytogenomic organizations from the rest of vertebrates (Table 1), although they show remarkable traits of convergent evolution with higher vertebrates (e.g., their adaptive immunity comparable with that of ours, [11]). However, lampreys and hagfishes differ also among each other, which is easily explained by their position on the phylogenetic tree, where five large extinct ( + ) groups are embedded between hagfishes and lampreys (although together known as cyclostomates):

Pteraspidiformest, Anaspidat, Thelodontiformest, Galeaspidiformest and Cephalaspidiformest [21,22]. It took another 65 myr for these fish to evolve jaws (chondrichthyans, ca. 420 mya). Here, we must be aware of the large gaps on the phylogenetic tree of living fishes, where other extinct lineages should have been 
otherwise placed (Placodermit, Acanthodiit; [21,22]. After the jawed fishes appeared, it took another $169 \mathrm{myr}$ to give rise to the ancestors of the living bowfin and gars (ca. 251 mya). However, both bowfin and gars are only the last survivors of much larger and very specious groups of once diversified and widespread lineages [23]. About 3 myr later, the ancestors of modern-day sturgeons and paddlefishes (Acipenseriformes) appeared (ca. 248 mya). The recent Acipenseriformes again represent only a small remnant group of once important radiations, whereas the order Paleonisciformest went extinct completely without any survivors left [21,22]. The modern-day teleosts, which rule the world's waters today, did not evolve until 225 mya. However, there was another completely extinct group embedded between Ginglymodi and teleosts, namely Pholidophoriformest, making the phylogeny around to the origin of teleosts extremely difficult and so far unresolved (the Halecostomi-Holostei problems, [24]). This large gap among the surviving lineages is beside outstanding issues in their morphology reflected also in their cytogenomic organization $[7,25]$ and illustrates the immense complexity and the current incongruence in the border(s) among Amiiformes (bowfin with its ancestors), Lepisosteiformes (gars) and teleosts. Originated in the marine realm, fishes radiated extensively in the sea [22] and colonized freshwater environments several times [26]. Immense selective pressures of these evolving environments must have shaped the genomes of untold thousands of fishes as they adapted to every conceivable ecological niche. Only recently, we have started realizing the extent to which the environment shaped their cytogenomic features $[27,28]$ but we still have to fully understand them. This long time that elapsed during fish evolution reflects in the broad variety of ways that the organization of the fish genome has been structured and re-structured among cyclostomates, chondrichthyans, non-teleost actinopterygians, fish-like sarcopterygians and teleosts (Table 1). In parallel, a comparable variety in genome organization occurs within teleosts, although more than $50 \%$ of their species displays $2 n=48-50$ [29]. This has to be regarded whenever any (cyto)genomic "generalizing" analyses are planned/performed. It is extremely simplifying to include merely $2-5$ teleost species and consider them sufficiently representative of approximately 26,000 living teleost species, not including other Actinopterygia e.g., [30]. Unfortunately, there are frequent reductions of "fish" to teleosts (e.g., [31], etc.) leaving the entire potential of Actinopterygia described above unutilized.

\section{The Importance of Fish Cytogenomic Research Demonstrated on Their Role in Medicine}

Approximately $70 \%$ of the genes associated with human diseases have their functional homologs in teleosts [32,33], although teleosts diverged from lineages leading to humans more than 400 mya and underwent a teleost specific whole-genome duplication (WGD). On the other hand, the copy number of $5 \mathrm{~S}$ and $45 \mathrm{~S}$ rDNA is tightly regulated in mammals [34] whereas incomparably relaxed in fishes [8,35]. Copy number variation between $5 \mathrm{~S}$ and $45 \mathrm{~S}$ rDNAs in humans and mice can result in cancer [36]. In fishes, variations in a much higher extent can result in a speciation event as documented e.g., in Coregonus (Salmoniformes, [35]), in Erythrinus (Characiformes, [37]) and other numerous examples. This demonstrates the importance of fish cytogenomic research in medicine and in our understanding of vertebrates' genome evolution. However, whereas the knowledge on mammalian (and yeast) rDNAs have already become established and currently receives its adequate attention with crucial findings being reported steadily. In fish, the research remains limited mostly to FISH (fluorescence in situ hybridization) detections of rDNA on chromosomes (for a survey see [38] or [39]) and to only several detailed molecular analyses of rDNAs in salmonids [40,41] and cichlids [42].

\subsection{Why Is the Zebrafish the Most Important Fish Model?}

Zebrafish (Danio rerio) have played an important role in accelerating our knowledge in embryonic development, regeneration, gene expression, transgenesis, environmental monitoring, drug discovery, cardiovascular diseases, immunology, infectious diseases, RNA splicing, stem cell biology and a host of other areas of importance to medical science [33,43-46]. At least $20 \%$ of the zebrafish's duplicated gene pairs have been retained from this WGD [47-50]. This often causes altered gene expression and protein functions, such that the complement of the expression domains of both fish paralogs are equivalent to the single orthologue in other vertebrates. Despite this WGD, zebrafish and humans 
have about the same number of chromosomes and zebrafish chromosomes are mosaically orthologous to several human chromosomes [50]. Cancer researchers use the zebrafish model to study vertebrate gene function [51] since its embryos are virtually transparent. This has led to much knowledge in gene function and genetic diseases [52-54]. Zebrafish have been used to make several transgenic models of cancer (melanoma, leukemia, pancreatic cancer and hepatocellular carcinoma; [44]). Zebrafish express mutated forms of either the BRAF (B-Raf) or NRAS (Neuroblastoma RAS) oncogenes and develop melanoma when placed onto a p53 deficient background. These tumors strongly resemble human melanoma. The BRAF melanoma model was used to understand the function of genes known to be overexpressed or amplified in human melanoma [51,55]. One gene, histone methyltransferase called SETDB1, markedly accelerated tumor formation in the zebrafish, demonstrating its role as a new melanoma oncogene. SETDB1 is further known to be involved in the epigenetic regulation central to tumorigenesis [51].

\subsection{Other Fish Species Used as Medical Models Have Genomes Suited for Specific Human Diseases}

The Japanese Medaka (Oryzias latipes) has a gene sharing over 95\% identity with the human HRAS gene, which is one of the most frequently mutated genes in cancers [45]. The medaka is a complementary model to the zebrafish as it has many of its desirable traits [56]. Among Antarctic notothenioids, the Antarctic rockcod (Notothenia corilceps) has an extra stout mineralized skeleton. Some of these fishes demineralize their bone to increase their buoyancy to the extent that they develop osteopenia, a bone loss very similar to osteoporosis. Certain cichlids serve as models of craniofacial developmental disorders to predict and treat human craniofacial disorders [57]. They have evolved very different craniofacial morphologies dependent upon the diet to which the particular species has specialized and genes responsible for their craniofacial adaptations have been discovered. The blind cavefish (Astyanax mexicanus) has both surface populations living in the light and cave populations living in total or near-total darkness with retinal degeneration and albinism $[45,58]$. Some studies have suggested that certain eye development genes (Paired Box 6 (PAX6), sonic hedgehog) are linked to eye degeneration [59]. Further questions are being currently solved since the full genome sequence of Astyanax is available [58] to determine the affected genes and elucidate their role in eye development [45]. Fair skin in fish and humans is predisposed to skin cancer. Also, the absence of melanin in the retina of cavefish may cause vision disease via often mutated gene OCA2 causing oculocutaneous albinism type II in humans [59] and is proof that the mutations in the same gene can result in the same phenotype in fish and humans [45]. Many killifishes (Cyprinodontiformes) make excellent models for aging research since they have adapted to life in the extreme conditions in the wet-dry savannahs of Africa. Eggs and embryos survive dry periods by undergoing diapause in the dry lake beds. When the rains come, they hatch quickly, and their life history is completed in the few months before the dry season arrives again. They have a very short lifespan even in aquaria under optimal conditions. Certain strains of this fish live only 10 weeks while others live 31 weeks. The fast aging in killifish show many of the same signs of older organisms, such as decreased fertility, cognitive decline, age-related molecular markers and high morbidity [60]. In the turquoise killifish, Nothobranchius furzeri aging is linked to an increase in cancer, infectious diseases, neurodegenerative diseases and circulation problems, hence this model is a useful model to study the aging process [60]. Toadfish (Batrachoididae) protects itself from predators by releasing urea to mask its scent and hiding spot and has a unique nitrogen excretion which makes them resistant to ammonia. Such a situation in the external or internal environment of humans would be harmful. The plain midshipman, Porichthys notatus, is a model for a human hepatic (portosystemic) encephalopathy, which is due to liver failure or excessive amount of nitrogen after kidney failure. The toadfish also serves as a model to study human sickle cell anemia and erythrocyte sickling under anoxic conditions. Under low oxygen levels, the toadfish's erythrocyte sickles similar to the human mutant, malfunctioning hemoglobin known as HbS [61]. Swordtails and platyfishes are one of the oldest animal models for cancer research. It was also the first to present evidence that cancer has a genetic basis. Certain 
hybrids of platyfish (Xiphophorus maculatus) and swordtails (X. hellerii) develop malignant melanoma. The genetics of the tumor formation is complex and has been well documented [62]. The Xiphophorus model has been widely studied in an effort to better understand the mechanism of melanoma formation in humans. The Xiphophorus model is well established as its three genomes has been sequenced ([63] and Appendix A). Eels (Anguilliformes) are excellent models of bone demineralization and childhood kidney cancer (Wilms' tumor). Physiological stress, fasting, or extensive migrations in eels cause bone resorption. Thyroid hormone has also been shown to be in involved in demineralization of their bone. An excess of the thyroid hormone can cause osteoporosis in humans, too. Wilms' tumor occurs naturally in a high percentage of eels in nature [45] and in 1 in 10,000 children at an early age. Eels form a natural model which is not available elsewhere in order to study this childhood tumor. The bicolor damselfish Stegastes partitus develops multiple neurofibromas and pigment-cell tumors [64]. Rainbow Trout (Oncorhynchus mykiss) is one of the oldest models for studying human liver cancer (hepatoma) since it is particularly susceptible to environmental carcinogens, especially aflatoxin B1 produced by Aspergillus. The hepatoma in trout is strikingly similar in histopathology to that in humans. Mutations in the Ki-ras2 Kirsten rat sarcoma viral oncogene homolog (KRAS) oncogene often resulting in hepatoma are common in both trout and humans. The trout has since been used to identify other environmental carcinogens. Conversely, several chemoprevention studies have been done to determine dietary supplements that inhibit hepatoma in trout previously exposed to aflatoxin [65]. The mummichog (Fundulus heteroclitus, Cyprinodontiformes) has adapted to hypoxic water conditions, extreme high and low water temperatures, high and low salinity and has developed a tolerance to toxic pollutants produced by municipal, agricultural and industrial sources, as well as to oils and gasoline from fishing and pleasure boat traffic. Its ability to adapt to such conditions make it a model for the study of physiological resilience and adaptation [66] and to study human health concerns relative to the widely varying environmental insults that we encounter almost daily.

\subsection{Amazon Molly (Poecilia formosa) as a Cytogenomic and Epigenetic Model Species in Human Health Research}

Amazon molly is a clonal species [67] and females do not undergo meiosis producing diploid eggs. When a male sperm from a related species stimulates the egg, it develops parthenogenetically-all offspring are clones genetically identical to their mother. This species has experienced first the classical cytogenetic phase of research (e.g., [68]), followed by genomics and (human) cancer research (oncogenomics) [66,67]. As a human disease model, the Amazon molly has been used in research into melanoma [69], infectious diseases [70] and thyroid cancer [71]. It is of interest that [69] introduced a microchromosome into Amazon molly genome inducing susceptibility to melanomas. The next stage was using zebrafish as a single gene knockout model in epigenetic cancer research. The histone demethylase, $K D M 2 A$, is thought to play a role in silencing transcription in humans. Otherwise, very little is known about its role in vivo in development and disease. Scahill et al. [72] discovered that the loss of the orthologous $k d m 2 a a$ in zebrafish is disruptive to transcriptional processes and produces a high frequency of melanomas. The discovery of the $k d m 2 a a$ mutants represents the first single gene knockout available for the study of melanoma induction. This zebrafish model is important as the World Health Organization reports 132,000 human melanoma skin cancers occur globally each year [72].

Fishes further represent important models also for environmental genomics [73] and for aquaculture genomics, genetics and breeding [74].

\section{3. rDNAomics-Where Fish Ecological Cytogenomics Meets Human Cancer Genomics}

Fish cytogenetics is largely based on chromosomal mapping DNA repeats that still represent serious obstacles in genome sequencing and assembling, even in model species. This has resulted in an immense amount of cytogenetic records including a still increasing number of "bursts" or "explosive spreading" of rDNA across chromosomes mostly in freshwater fishes. Only the availability 
of combined genomic data (e.g., Illumina and PacBio in the case of pikes, [8]), has enabled to quantify these extremely amplified rDNAs and to analyze them in a broader molecular context. At the moment, such data are available only for Esox lucius and they show that the copy number of the 5S rDNA fraction corresponds to the entire human gene number, i.e., about 20,000 5S rDNA copies. This means that in pike solely the 5S rDNA expanded to such an extent inconceivable in human or mouse genome and left the $45 \mathrm{~S}$ rDNA fraction unamplified. Based on currently available cytogenetic data, similar situation in the $45 \mathrm{~S}$ rDNA fraction can be expected in salmonids and in other fish groups (e.g., erythrinids, etc.) with the awaited increasing availability of hybrid sequencing. Then, we will be able to better analyze the causes and consequences of these phenomena. The results presented by the Animal rDNA Database [39] indicate that the freshwater environment might have favored these extreme amplifications of only one of the two rRNA gene fractions. This clearly rules out the primary ribosomal function of amplified rDNA molecules. Below in Figure 1 we summarize and visualize our current knowledge on coding and non-coding (non-ribosomal) functions and roles of rDNA generally and in the case of formation of reproductive barriers in fishes. The origin of these copy number bursts of rDNAs might be potentially related to the "rRNA gene amplification system," which is finely tuned to maintain or, when necessary, to recover a particular and species-specific number of rDNA copies (explained by [75], section 10.4). The exact molecular mechanism(s) are the matter of vivid discussions and speculations at the moment (e.g., [8]) and include among others unequal sister chromatid recombination or retrotransposition. However, evidence accumulates that nucleolus (i.e., sites of the active rDNA transcription) and alone the rDNA copy number are involved in human diseases, cancer predisposition and other oncogenic activities related to genomic instability [76-78].

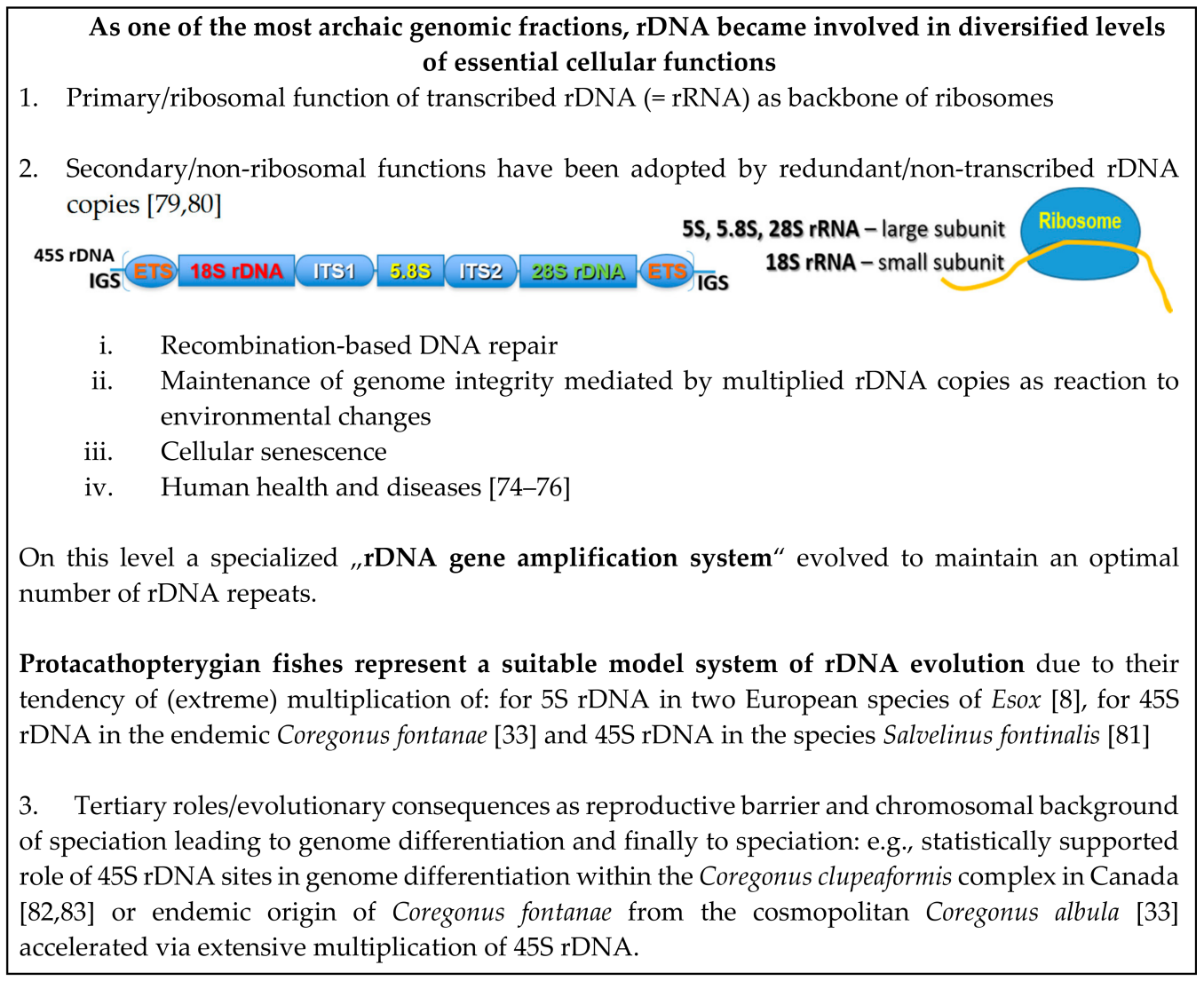

Figure 1. Three levels of ribosomal DNAs (rDNAs) functionality, generally and specifically in fishes. 


\section{State-of-the-Art in Fish (Cyto)Genomics-The Starting Point}

Several reviews on fish genomics have been published during 2003-2013 [77,78,84] and one recent (2016) special issue called 'Fish, Genes and Genomes: Contributions to Ecology, Evolution and Management' [85], which is mostly focused on population genetics and population and conservation genomics. In the meanwhile, numerous fish genomes have been published and several major milestones have occurred in the field of fish molecular cytogenetics: (1) Fish Karyotypes was published [86] — this immense work summarized previous knowledge and still provides a valuable reference overview of karyotypes and where available other karyological and cytogenetic traits in 3425 species/subspecies of extant jawless, cartilaginous, ray-finned and lobe-finned fishes and becomes thus an important reference tool; (2) A still continuing boom of FISH technique in fish resulting in the still increasing amount of molecular cytogenetic data; (3) Availability of more sophisticated and informative methods like GISH (genomic in situ hybridization) and CGH (comparative genomic hybridization) in fish resulting in comparative studies ([35,87,88] and more); (4) Large fish genomes with record chromosome numbers have been documented and analyzed and shifted the limits of fish genome size ([89] Acipenser brevirostrum, A. mikadoi, Diptychus dipogon). In parallel, the first non-human vertebrate and at the same time the first fish genome has been published-the Takifuga rubripes and two other pufferfish genomes thereafter (T. flavidus and Tetraodon nigroviridis) followed by newer versions of their genome assembly (details below). These fishes are of tremendous interest to fish cytogenomicists and generally to vertebrate genomics since they involve several crucial phenomena of the fish genome evolution that still represent outstanding questions. They have the smallest known of vertebrate genomes (350-500 Mb, [90]; Appendix A), which was the impetus for their sequencing. This among others enabled the first accurate prediction of the number of human protein coding genes [91]. However, their compact genomes retain similar chromosome numbers as teleosts with doubled genome size (i.e., $2 n=42 / 44)$, ([90]; Appendix A). Another notable feature of the tetraodontid genome its increased GC content-their GC-rich regions are gene-rich as in mammals [90], although the typical mammalian type of chromosome banding does not occur in pufferfishes [7]. On the other hand, there are other teleost species with comparably high genomic GC content (e.g., Clupea, Gasterosteus, Gadus, for details see Appendix A), however, without the extreme genome size reduction and genome compactness as in tetraodontids. A situation so far unprecedented among all fishes has been documented in extant gar genera (Atractosteus and Lepisosteus, Lepisosteiformes). Although their genomic GC content is not so increased as in pufferfishes, or as in other aforementioned species with unreduced genome size, their AT/GC compositional heterogeneity is unparalleled among cold-blooded vertebrates and is cytogenetically detectable in the same way as in mammals i.e., G-banding and AT/GC banding functionality [7]. This briefly illustrates the extent and the complexity of genome organization within fishes and the need to exploit the available resources in integrative cytogenomic approaches to at least partly clarify factors involved in the evolution of functional genome organization in vertebrates. 
Table 1. Main cytogenomic traits in fish-like chordates.

\begin{tabular}{|c|c|c|c|c|c|c|}
\hline Group & $\begin{array}{l}2 n \text { Chromosome Counts } \\
\text { (Basic Features) }\end{array}$ & Micro- Chromosomes & CG Heterogeneity & $\begin{array}{l}\text { WGD after the First Two } \\
\text { Basal Vertebrates' WGDs }\end{array}$ & $\begin{array}{l}\text { C-Value/Haploid DNA } \\
\text { Content (pg) [12] }\end{array}$ & $\begin{array}{l}\text { Specific Features in the } \\
\text { Genome History and } \\
\text { Chromosomal Evolution }\end{array}$ \\
\hline Myxiniformes (hagfishes) & $14-48$ & NO & unknown & not observed & Myxinidae 2.5-4.59 & $\begin{array}{l}\text { chromatin diminution, } \\
\text { programmed genome } \\
\text { rearrengement }[13,14]\end{array}$ \\
\hline $\begin{array}{l}\text { Petromyzontiformes } \\
\text { (lampreys) }\end{array}$ & $76-178$ & NO & GC-rich DNA repeats & not observed & Petromyzontidae 1.29-2.5 & $\begin{array}{l}\text { programmed genome } \\
\text { rearrengement [14] }\end{array}$ \\
\hline $\begin{array}{l}\text { Chondrichthyes } \\
\text { (cartilaginous fishes) }\end{array}$ & $54-102$ & YES & $\begin{array}{l}\text { observed, presumably satellite } \\
\text { DNA }\end{array}$ & not observed & $\begin{array}{l}\text { Chimeriformes 1.5-2 } \\
\text { Selachimorpha } \sim 3-17 \\
\text { Rajimorphii } 2.7-17\end{array}$ & $\begin{array}{l}\text { AT/GC heterogeneity } \\
\text { positively correlated with } \\
\text { genome size [15] }\end{array}$ \\
\hline $\begin{array}{l}\text { Ceratodontiformes } \\
\text { (lungfishes) }\end{array}$ & $34-68$ & $\begin{array}{l}\text { Only N. forsteri [15] } \\
\text { otherwise not }\end{array}$ & unknown & not observed & $\begin{array}{l}\text { Neoceradotus } 52.75-74.86 \\
\text { Lepidosiren } 80.55-123.9 \\
\text { Protopterus } 40-132.8\end{array}$ & $\begin{array}{l}\text { "genomic obesity" without } \\
\text { WGD documented [16,17] }\end{array}$ \\
\hline $\begin{array}{l}\text { Coelacanthiformes } \\
\text { (lobe-finned fishes) }\end{array}$ & 48 & YES & unknown & not observed & Latimeria $2.8-6.6$ & $\begin{array}{l}\text { chromosomes similar to } \\
\text { ancient frogs [18] }\end{array}$ \\
\hline $\begin{array}{l}\text { Acipenseriformes } \\
\text { (sturgeons, paddlefish) }\end{array}$ & $\sim 120-240-360$ & YES 50\% & $\begin{array}{l}\text { NORs and GC-rich } \\
\text { microchromosomes [7] and } \\
\text { G-banding }[19,20]\end{array}$ & $\begin{array}{l}\text { multiple in sturgeons, one in } \\
\text { paddlefish }\end{array}$ & $\begin{array}{l}\text { Acipenser } 1.8-9.3 \\
\text { Polyodon } 1.6-2.4\end{array}$ & $\begin{array}{l}\text { multiple WGD, ploidy } \\
\text { diversity }\end{array}$ \\
\hline Lepisosteiformes (gars) & $56-58$ & small sized chromosomes & in both genera & not observed & $\begin{array}{l}\text { Atractosteus } 1.2 \\
\text { Lepisosteus } 1.4\end{array}$ & $\begin{array}{l}\text { regionally high recombination } \\
\text { rate }\end{array}$ \\
\hline Amiiformes (bowfin) & 46 & NO & only NORs & not observed & Amia calva 1.2 & $\begin{array}{l}\text { convergent evolution with } \\
\text { teleosts? }\end{array}$ \\
\hline Polypteriformes (bichirs) & $\begin{array}{l}\text { 36-38 biarmed, } \\
\text { extremelly large }\end{array}$ & NO & only NORs & not observed & $\begin{array}{l}\text { Erpetoichthys } 4.5 \\
\text { Polypterus } 3.6-7.2\end{array}$ & not investigated \\
\hline Teleostei & $\begin{array}{l}50 \text { (exceptions up to } \\
100-150 \text { or more) }\end{array}$ & Micro B-chromosomes & only NORs & $\begin{array}{l}\text { TGD and lineage specific } \\
\text { WGDs }\end{array}$ & mostly 0.4- 1.0 & $\begin{array}{l}\text { from genome compaction to } \\
\text { lineage specific WGD }\end{array}$ \\
\hline
\end{tabular}

WGD: Whole-genome duplication; NOR: Nucleolar organizer region; pg: picograms. 


\section{Fish Cytogenomics-Practical Application of Integrated Cytogenetics and Genomics}

\subsection{Assignment of Linkage Groups to Specific Chromosomes Using FISH with Sequenced BACs}

This approach has been so far applied only in several model fish species: zebrafish [92], rainbow trout [93], Atlantic salmon [94], Nile tilapia [95]. However, due to the workload required not all species have been processed in this way and even in species with genomes assembled to the chromosome level their linkage groups (LGs) still have not been assigned to chromosomes. Hence, there still exists need to continue in this effort in model as well as non-model species e.g., spotted gar [7,82], Lake Whitefish [83,96], Northern pike [97], etc. that will finally allow for down-stream analyses and combinations of data obtained by molecular cytogenetics and genome sequencing. This is crucial e.g., to explore the (1) genomic context of the rDNA sites on specific chromosomes; (2) the DNA sequence of centromeric and pericentromeric regions that frequently harbor diverse repetitive elements and show either AT- or GC-richness; finally, (3) identification of residual tetrasomic sites in paleo-tetraploids (salmonids) which is currently impossible by means of genomic and bioinformatics tools [98]. However, using FISH mapping of BACs, we have identified already two of eight predicted residually tetrasomic sites (i.e., sites preserving the ancestral tetraploid condition within the otherwise secondary diploidized genome) in the Lake Whitefish (C. clupeaformis, [99]).

\subsection{Quick Qualitative Analysis and Visualization of AT-vs. GC-Rich Chromosomal Regions}

Quick qualitative analysis and visualization of AT vs. GC rich chromosomal regions utilizing fluorescent staining specific for AT (DAPI) and for GC (Chromomycin $\mathrm{A}_{3}\left(\mathrm{CMA}_{3}\right)$, 7-amino-actinomycin D (7-AAD), propidium iodide). This is a particularly useful approach in combination with bioinformatics analysis producing AT/GC profile across chromosomes/LGs hence quantifying cytogenetic data. Basically, there are two possible approaches producing AT/GC profiles across linkage group/chromosome: (1) chromoplot [7] calculates and plots the absolute GC percentage (Figure 2) or (2) the tool isoSegmenter [100] segmenting genome into pre-defined and broadly used concept of "isochores" (i.e., large genomic regions homogeneous in their GC content, sensu [101]). This DNA compositional cytogenomics gained in importance due to the recently uncovered AT/GC compositional heterogeneity in the ancient gars [7]. This finding means that it is crucial (a) to change our attitude to generally accepted compositionally homogenous fish genomes, which is not true anymore; (b) to revisit the so far obtained results and to employ e.g., the simultaneous DAPI/CMA 3 staining together with attempts of G-banding in fishes. Some authors tend to present DAPI stained metaphases separately from the $\mathrm{CMA}_{3}$ stained ones or not to show one of them. This makes the situation complicated for any serious reason and does not allow for proper exploitation of the data (i.e., a part of information would be missing despite its actual availability); (c) this sheds new light on the vertebrate genomic DNA composition generally because so far the broadly accepted concept has considered fish and amphibians AT/GC homogenous whereas only birds and mammals were AT/GC heterogeneous, with transient situations in reptiles [101]. However, the bromodeoxyuridine (BrdU)/pulse replication labeling does produce reproducible bands in both compositionally heterogeneous higher vertebrates and homogenous fish and amphibians (e.g., for fish [102]). Therefore, in the light of findings in gars and the bowfin, it would be highly desirable to perform a large-scale comparative cytogenomic study across fishes to be able to exactly analyze the potential banding pattern in fishes so far considered compositionally homogenous. Namely, the BrdU banding pattern should provide a "scaffold" of expected bands, which should be then analyzed with DAPI/CMA 3 and in parallel on the LG profiles. In this way, we should be able to quantify the cytogenetic thresholds of chromosomal band visualization and make the approach of chromosomal banding more sensitive to the putative less heterogeneous pattern in fish genomes. This step will be essential to properly understand the issue of compositional organization of fish and amphibian versus avian and mammalian genomes and finally the vertebrates' genomes generally. The quantification on AT/GC profiles will require higher versions of better genome assemblies assembled to the chromosome level and with already filled gaps (or filled as much as 
possible). This means, that the so far available versions of genomes were not yet suitable for these analyses and hence, fish researchers have not yet missed anything.
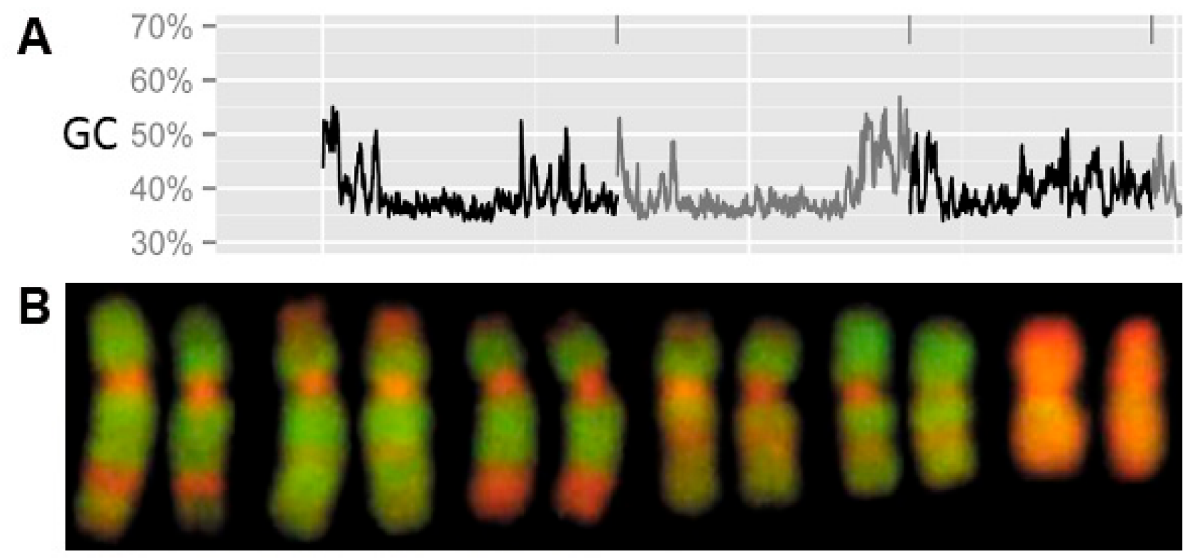

Figure 2. (A) GC-profiles across three linkage groups (LGs) so far unassigned to their corresponding chromosome pairs showing fluctuations in GC-percentage produced using the chromoplot tool. These three linkage LGs are arranged according to their numbers in the Ensembl [103] and separated by vertical lines above profiles and by the alternation of gray and black colors ( $x$-axis-genome position, $y$-axis-GC\%); (B) Partial karyotype stained with 4',6-diamidino-2-phenylindole/ Chromomycin $\mathrm{A}_{3}$ $\left(\mathrm{DAPI} / \mathrm{CMA}_{3}\right)$ showing six pairs of larger chromosomes of the spotted gar with altering GC-rich regions in red and AT-rich regions in green. Reproduced with permission from [7].

\subsection{Cytogenetic Mapping of Repetitive Sequences on Conspecific Populations}

Cytogenetic mapping of repetitive sequences on conspecific populations exploring their participation in evolutionary diversifications of different vertebrate species. In studies by $[83,96]$, population molecular cytogenetics was shown to be an irreplaceable tool in exploring the population dynamics of rDNA sites. On the example of the Lake Whitefish (Coregonus clupeaformis, Salmonidae), we have documented that the differential dynamics of rDNAs across chromosomes participate in the evolutionary diversification of fish genomes. Similar studies performed in Erythrinidae (Characiformes) e.g., by $[37,104]$ (this issue and citations therein) show comparably high intra-species evolutionary dynamics in rDNA and also other repetitive DNA in the genera Erythrinus and Hoplias. These and other similar finding originating from freshwater fish groups show the relevance of the FISH-based rDNA mapping (1) for understanding evolutionary mechanisms underlying ecological speciation [35] and (2) as an important tool how to tackle incipient and established biodiversity [105].

\subsection{Cytogenomics of Duplicated Genomes-Understanding Mechanisms of Genome Evolution in Vertebrates} Which Have Undergone Whole-Genome Duplication(s)

Whereas there are no further WGD events in higher (warm-blooded) vertebrates, in lower vertebrates, particularly in fishes (recent review by [106]) but also in amphibians and to some extent in reptiles [107], there are numerous examples of WGDs. Hence, fish genomes offer irreplaceable insights into the diversity of evolutionary patterns in Sarcopterygia and Actinopterygia (Table 1). However, to sequence and above all to assemble such genomes remains challenging (bichirs, lungfishes, sturgeons, salamanders). Hence, the "classical" cytogenetics still represents an important tool to analyze these genomes and the post-WGD evolution $[20,89,108]$. Not only in these cases, cytogenetics can largely benefit from genomics and bioinformatics and compensate for the obstacles during sequencing and genome assembling ([19], this special issue). 


\section{Fish Cytogenetics and Cytogenomics in the Era of Digitalized Biology-The Boom of Databases}

\subsection{Databases for Fish Biology}

Currently, fish genetics is beginning to benefit from increasing diversified efforts to build databases to compile and curate the increasing amount of molecular data on fish genomes. Hence, despite the devotion to fish genomics of the Indian subcontinent, we can explore and utilize in evolutionary studies e.g.: "FBIS: A regional DNA barcode archival and analysis system for Indian fishes" introduced by [109], "FMiR: A Curated Resource of Mitochondrial DNA Information for Fish" introduced by [110], "FishMicrosat: a microsatellite database of commercially important fishes and shellfishes of the Indian subcontinent" by [111]. Microsatellites of 31 fish species not confined to India are available in the microsatellite database MSDB [112]. The particularly important tool "Fish Karyome" is now available in its upgraded version [113]. Beside these four tools originating from India, the Animal rDNA database [39] including in its current version 546 fish and fish-like species is a highly relevant and informative tool usable in evolutionary-ecological fish cytogenomics or rDNAomics. Genome size of more than 2000 fish and fish-like species is currently available at the online database [12]. General data about fish biology, ecology and biogeography are already traditionally provided by Fishbase [114] and represent the first-choice tool for any evolutionary studies, including cytogenomics, in the ecological context. An online database specialized on B chromosomes and involving fishes is described in the Section 8.2 dealing specifically with B chromosomes.

\subsection{History of the Zebrafish Reference Genome}

History of the zebrafish reference genome started in 2001, when the Wellcome Trust Sanger Institute initiated the zebrafish genome-sequencing project and selected the Tübingen zebrafish reference strain as it had been widely used to identify mutations affecting embryogenesis. The Zv8 assembly was a hybrid of high-quality clone sequence (83\%) and whole-genome shotgun (WGS) sequence $(17 \%)$, with a total size of 1.412 gigabases $(\mathrm{Gb})$. The clone and WGS sequence is tied to a high-resolution, high-density meiotic map called the Sanger AB Tübingen map (SATmap). This full genome sequence was made available to the public at the NCBI Zebrafish Genome Page and is maintained by the Genome Reference Consortium (FishMap Zv8 [115]). In 2009, the Institute of Genomics and Integrative Biology in India sequenced the genome of a wild zebrafish strain. The genome contained about $1.7 \mathrm{~Gb}$ and when compared to the Zv8 variations were found in over 5 million nucleotides and over 1.6 million indels. Later, the zebrafish reference genome was published, consisting of $1.4 \mathrm{~Gb}$ and over 26,000 protein-coding genes [32]. After the release of the Zv8 project, they joined the Genome Reference Consortium (GRC) for further improvement and maintenance. The GRC has now released a new reference assembly, GRCz11. Sanger's GRC partners at the ZebraFish Information Network (ZFIN) continue in updates and maintenance. In parallel, Amores \& Postlethwait [116] recognized a need for molecular cytogenetics in zebrafish and performed an exhausting study to facilitate the unambiguous cytogenetic identification of each individual chromosome. Several further molecular cytogenetic studies localized repetitive sequences in zebrafish [117-119].

\subsection{Fish Genomes Available}

Using the NCBI Genome Browser [120] and filtering for the Kingdom "Eukaryota," Group "Animals" and Subgroup "Fishes" we find further about 90 fish species with genomes sequenced and assembled to the diverse levels. Additional fish species with a sequenced genome available can be found in a literature search resulting at the moment with about 95 species. These currently available species are listed in Appendix A, an online continuously updated version of this list will be available on the web page [121]. This list in alphabetical order includes: 2 lancelets, 1 hagfish, 2 lampreys, 1 shark, 1 ray, 1 gar representing the non-telesost Actinopterygia, more than 80 teleosts and 1 coelacanth 
of the group Sarcopterygia. In this dataset, we integrate basic genomic with basic cytogenomic traits-genome size in $\mathrm{Mb}$ based on sequencing, genome size as $\mathrm{C}$-value originating from [12]; linkage groups (haploid) and diploid chromosome numbers; level and number of assemblies (i.e., draft, contig, scaffold, chromosome level), genomic GC percentage and sequencing platform applied emphasizing the PacBio technology with its particular relevance for chromosomal and repetitive DNA studies. The phylogenetic "coverage" of sequenced fish and fish-like species is provided in Appendix A and will be also online and continuously updated. Some of the model fish species have been (re)sequenced and (re)assembled up to 4, 5 times (see column \#Assembly in Appendix A; details e.g., at [122] or at the Genome Assembly Database of the European Nucleotide Archive (ENA, [123]). Importantly, each new version means filling more gaps, improving scaffolds towards the chromosome level, improving of genome size estimations and proportion of repetitive sequences e.g., [124].

Sometimes substantially different results are found than in the previous genome versions (e.g., in Atlantic cod, [124]). Moreover, there are strong indications that numerous non-model genomes contain widespread and predictable assembly and annotation errors [30], which means that using their improved versions will be critical. Other de novo draft genome assemblies of 66 teleost species are available through [125] (these species will be included in further online version of Appendix A). Further, the Genome 10K Project aims to sequence and analyze 10,000 vertebrate species including fish and hence other fish genomes are expected to be available in the future [126]. Beside the aforementioned genomic sequences, 24 fish transcriptomes are available through the PhyloFish database [127]. On the top of that the Fish T1K platform announced transcriptomes of 124 actinopterygian fish species (covering 46 orders and 99 families) to have been already sequenced and further 59 species were in progress [128]. Since this web-based information has been updated only in 30 April 2015, the results might have been already substantially more progressed. Genomes assembled to the chromosomal level are particularly important for cytogenomics—currently there are 18 species (see Appendix A). Once the available linkage groups (LGs) are assigned to their chromosomes, the cytogenetic results will be directly applicable in genomic data and vice versa. This is however, still in the future, hopefully not too far away.

\subsection{Future of Fish Cytogenomics $=$ Phylogenomics}

The abovementioned tools are together with the most recent fish phylogenetics published by [22] and [10], an excellent starting point for the application of modern phylogenetic comparative [129] and other quantitative methods exploring cytogenomic phenomena in the broader eco-evo context.

\section{Quantitative Eco-Evo Cytogenomics}

Fishes are the only group of vertebrates, where relationships between genome size and essential cellular parameters, sometimes called cytogenomic ratio, remain uncertain [130]. In fish, similarly as in other vertebrates and eukaryotes generally, two opposite sets of theories attempt to explain the mechanisms behind the large variation in the amount of non-coding DNA-adaptive and non-adaptive theories [131-133]. Genome size is negatively correlated with GC percentage in several fishes, like Tetraodon, Takifugu, Gasterosteus, etc. (Appendix A). On the other hand, also larger fish genomes show GC increment (Clupea, Gadus) or even the mammalian like GC heterogeneity (gars, [7]). There is also a clear effect of environment and life-style on the GC content in teleosts [134]. Further, genome size obviously correlates with chromosome numbers, although considerable modifications in genome size can occur largely independent of changes in chromosome counts [29]. Here, the role of environment has been already repeatedly evidenced: occurrence of larger genomes in freshwater versus marine fishes $[28,135,136]$, so far not recorded polyploidy in marine actinopterygians versus frequent incidence of polyploidy among chondrichthyans [12,15] and freshwater actinopterygians [28,29] and higher cytogenomic ratios in chondrosteans than in actinopterygians as in cold-water fishes relative to their warm-water counterparts [130]. These few examples show the complex network of 
numerous interactions on diverse levels ranging from molecular, over developmental, physiological and life-history traits to the environmental.

However, we still need to better explore and understand all these levels and the interactions, since there are several major topics and related outstanding issues in fish quantitative eco-evo cytogenomics, where the genomics resources, e.g., data on exon/intron sizes and counts will be highly desirable to complement the existing robust datasets obtained from cytogenetics and flow cytometry: (1) the conundrum of remarkably constant diploid chromosome number (48-50) even among species that differ significantly in DNA content $[28,135]$ - are there any phylogenetic constrains and/or selective pressures directing chromosomal evolution towards $2 n=48-50$ ? In other words, do we have to look for potential nucleotypic limitations of genome size on cellular and organismal phenotypes? i.e., any links between rate of development, life-span length, metabolic rate, body size and cytogenomic parameters?; (2) the role of water environment (freshwater $\mathrm{x}$ marine) in the dynamics of evolution of genome size, chromosome number, fundamental number etc.-occurrence of larger genomes in freshwater versus marine fishes $[28,135,136]$; (3) generally the incidence of polyploidy only in the freshwater environment with the exception of chondrichthyans; (4) origin of the genomic gigantism (obesity) in lungfishes and bichirs [12,17,137].

Utilizing increasingly available karyological and cytogenetic data, several attempts have been performed to quantify these purely qualitative data and assess them in ecological, life history traits and physiological context. In this way, chromosome and chromosome arms (FN) numbers have been compared as a measure of chromosomal dynamics several times [138]. These studies indicate a chromosomal stability and conservatism in marine fishes although limited to restricted regions and groups [138]. All these studies represent important first steps although they are largely limited to a narrow subset of fish lineages, limited geographically and certainly not exploiting the available data and advanced cytogenomic methods. However, there is an essential shift from the previous mostly descriptive approach towards understanding the phenomena observed at the functional stage.

\section{Sex and B Chromosomes, Nuclear Architecture and Genome Evolution Research}

Here we summarize three further aspects of genome evolution, where rDNA does play an important role and where the integrative cytogenomic already proved its potential. B chromosomes were among others proved to originate from sex chromosomes [139] or to interact with sex determination [140].

\subsection{Sex Chromosomes in Fish}

Sex chromosomes in fish are exhaustively discussed in another paper of this special issue and illustrated on the well explored example of Neotropical fishes [104]. We would like to highlight the contribution of rDNA regions in sex chromosomes evolution $[104,141]$ and the cytogenomic approach that proved successful in combining both cytogenetic and genomic data e.g., [141] in the two most important model species. The mechanism of sex-determination in zebrafish is of importance to understand if it is to serve as a vertebrate model system to study human development and disease. However, past researchers have failed to find either an XY, ZW, multiple sex-determining mechanism, or environmental determination. Recently, using cytogenomics, this question has been mostly answered. A novel genetic map of single-nucleotide polymorphism (SNP) was used in a genome-wide linkage study of sex-determination in zebrafish [142]. Loci were identified on zebrafish chromosomes 5 and 16. Chromosome 5 locus contains $d m r t 1$, a gene found in sex determination from fruit flies to humans. A mutation in the orthologue of this gene in humans results in complete sex reversal of $X Y$ individuals. Chromosome 16 contains cyp21a2. Mutation of the human orthologue of this gene is a common cause of pseudohermaphroditism. Recently, zebrafish chromosome 4 has been identified as a sex chromosome along with the sex-linked genes on chromosomes 5 and 6 discussed above [143]. In zebrafish, there is a combination of effects on the genome, germ cells and the environment with influences from epigenetic factors. However, the primary factors in 
sex-determination in zebrafish remain controversial [143]. The Japanese Medaka has an XX-XY chromosome-based sex determination similar to mammals with the male determining master regulator genes on the $\mathrm{Y}$ chromosome. Interestingly, this mode is not conserved even within the genus Oryzias [144].

\subsection{B Chromosomes (Not Only) in Fish}

B chromosomes (not only) in fish is another area of biology, where cytogenetics successfully and productively meets genomics and rDNAomics [145,146]. B chromosomes are known to contain rDNA frequently e.g., [147], summarized by [79,139]. B chromosomes have been identified e.g., in seven South American and in fourteen African cichlid species [143], in the genus Poecilia as we already mentioned by [148], in the bleak (Alburnus alburnus, Cyprinidae) [149] and in three species of thorny catfishes [150]. The complete list of B chromosomes identified in fishes is available in a specialized database 'B chrom' [151] by [152]. There are 278 entries are listed comprising approx. 120 species (depending on the species status and the level of species identification; accessed on 24 January 2018).

\subsection{Nuclear Architecture}

Nuclear architecture-nucleolus and rDNA emerged as important components of the nuclear architecture [78] and as indispensable components of mechanisms maintaining genomic integrity [81,153,154]. Moreover, the repetitive nature of rDNA and other repetitive genes (e.g., histones) results in a high evolutionary dynamics, known also as evolutionary hotspots [80,155]. Therefore, to understand the complex evolutionary structural as well as functional, mechanisms in vertebrate genomes, it is crucial to view the current cytogenomic knowledge also in the context of nuclear architecture, regulation of gene expression, role of transposons and epigenetics. At this stage, any attempts to explore structural aspects of interphase nuclei in fishes generally are missing. The single study on basic organization of two cold-blooded vertebrate genomes by [156] demonstrated that gene-rich regions in one amphibian (Rana esculenta) and one reptile (Podarcis sicula) occupy the more internal part of the nuclei, whereas the gene-poor regions occupy the periphery. This finding is similar to that previously reported in warm-blooded vertebrates, despite the lower GC levels of the gene-rich regions of cold-blooded vertebrates [156] and citations therein. In Atlantic cod, Kirubakaran et al. showed an example of putative directional selection for retaining two adjacent inversions on LG1 [157]. These inversions repress meiotic recombination in crosses. Moreover, the chromosomal block with these inversions harbors 763 genes, including candidates regulating swim bladder pressure, heme synthesis and skeletal muscle organization conferring adaptation to long-distance migrations and vertical movements down to large depths. Despite interbreeding between forms with (migratory ecotype) and without (stationary ecotype), the inversions are maintaining genetic differentiation [157].

\section{Roots of (Population) rDNAomics in Fish Cytogenetics-rDNAomics as Another Dimension of Environmental Genomics}

There is a long tradition in chromosomal mapping of rDNA sites in the fish cytogenetics. This descriptive and qualitative work resulted in astonishing findings of extremely multiplied rDNAs, both $45 \mathrm{~S}$ and $5 \mathrm{~S}$ rDNA $[8,35,37,158]$, for numerous other examples, see the animal rDNA database [39]. Mapping of rDNAs (but also of other highly repetitive DNA fractions as e.g., histones and transposons $([159,160])$ across populations proved to be an important tool to explore the (sub)chromosomal background of populations' diversification, incipient speciation and finally completed speciation events. These repetitive sequences appear to evolve at a higher rate and their mapping hence enables to catch various stages on the gradient of genome diversification, sometimes even stages that are not distinguishable on the morphological or genetic level ([161] vs. [35]). However, only in combination with other molecular methods and genomic data, a precise quantification and detailed insight became possible [8]. In this way, we documented a peculiar higher-order organization of the extremely amplified, potentially functional and massively methylated 5S rDNA in two species of European pikes, 
whereas the $45 \mathrm{~S}$ rDNA fraction was ascertained in both of the pike species not to have undergone any amplification (Figure 3).

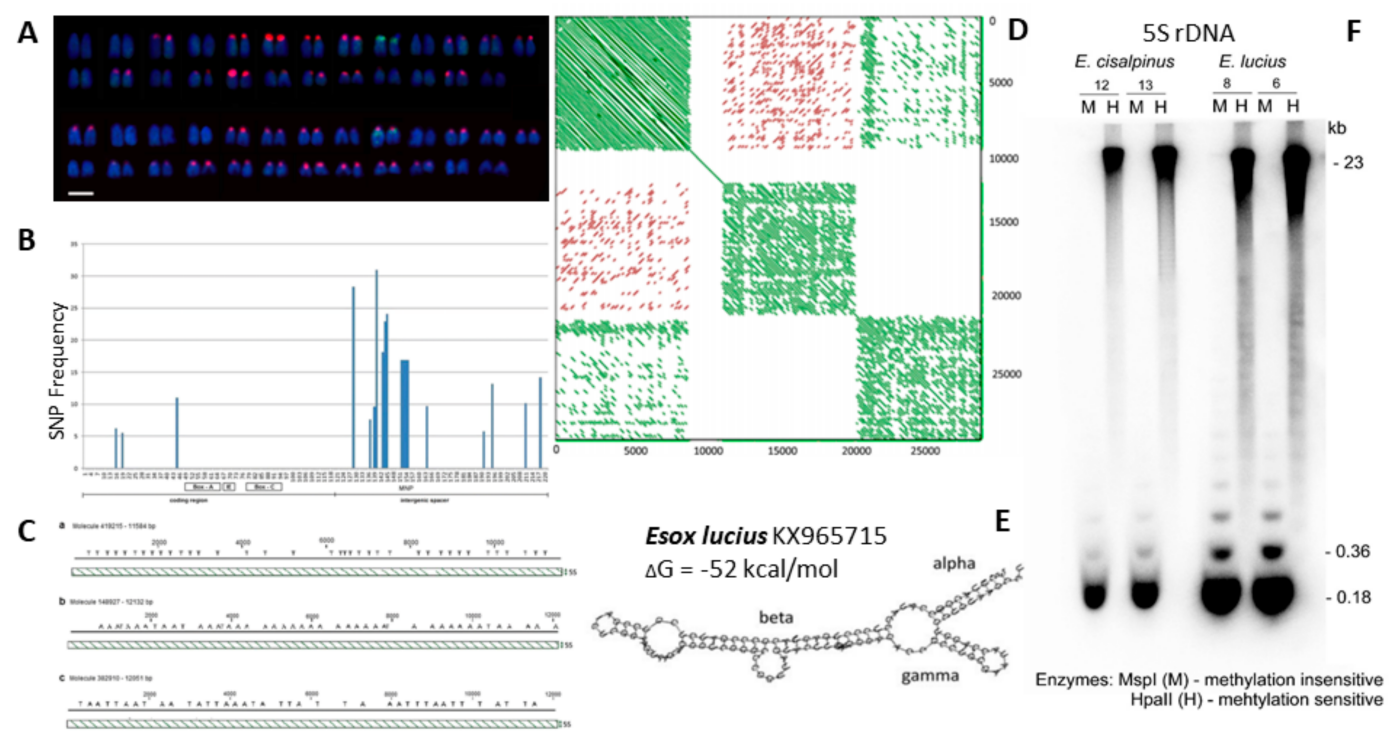

Figure 3. Summary of an integrative cytogenomic study on the rDNAome in European pikes (Esox lucius and E. cisalpinus). (A) Fluorescence in situ hybridization (FISH) with 5S rDNA (red) and $45 \mathrm{~S}$ rDNA (green); (B) Distribution of single-nucleotide polymorphism (SNPs) along the E. lucius $5 \mathrm{~S}$ rDNA unit obtained from Illumina reads showing absence of SNPs in the internal controlling region composed of Box-A, IE and Box-C elements; (C) Distribution of variants in intergenic spacer regions (IGS) in three PacBio reads $(a-c)$. Slanted lines indicate tandemly arranged units visualized through the alignment of reads ( $x$-axis) with a $5 S$ gene ( $y$-axis); (D) Higher-order organization of $5 S$ rDNA arrays in E. lucius. Self-to-self comparison of long PacBio molecules representing three groups; (E) 5S rRNA domain reconstruction of E. lucius indicating its potential functionality; (F) Methylation analysis of $5 S$ rDNA by the methylation-sensitive HpaII $(\mathrm{H})$ restriction enzyme and its methylation-insensitive MspI (M) isoschizomere. Reproduced from [8].

Interestingly, Salmoniformes, the sister lineage of Esociformes, where pikes belong to, tend to amplify $45 S$ rDNA with mostly stable and low 5S rDNA copy numbers [35]. Hence, this whole group of Protacanthopterygia (i.e., Salmoniformes and Esociformes, [20]) provides a suitable model system for further exploring and above all understanding the evolutionary dynamics of their rDNAome. Already the available findings in fish rDNAs are crucial since they show the immense differences between the genome and rDNAome complexity in lower and higher vertebrates. Namely, the discrepancy between copy number of $5 \mathrm{~S}$ and $45 \mathrm{~S}$ rDNA (e.g., [76]), which is being tolerated by fish and contributes to genomes diversification, speciation and finally to increase in biodiversity $[8,35,83,96]$. In mammals, differences in copy number between $5 \mathrm{~S}$ and $45 \mathrm{rDNAs}$ has been proved to be involved in pathological conditions.

\section{Conclusions}

Nucleolus and rDNAs are the hub integrating environmental and intracellular signals [81] and the cellular stress sensor [153]. Moreover, rDNA copy number has been shown to play a crucial role in maintenance of the genome integrity and onset of diseases and senescence [162]. Therefore, the integrative cytogenomic analysis of not only fish rDNAomes represents another, so far unexploited, dimension of the genomics in fish sensu [73] and allows alternative insights into the complex interactions between cells and organisms and their environment. In future, more systematic studies on molecular cytogenetic detection of 5S and 45S rDNA in different populations and/or species 
will enable us to assess the role of rDNA spreading across chromosomes in genome differentiation at different environmental conditions. As we showed, the vertebrates' rDNAome still represents a largely underestimated and unexploited genomic fraction with the huge potential to elucidate and proper understand crucial genomic functions and above all genome's interactions with the environment.

Acknowledgments: R.S. was supported by the Faculty of Science of the University of Hradec Králové. The costs of open access were covered by funds of the University of Hradec Králové provided to R.S. This study was supported by Specific Research Project from University of Hradec Kralove Nr. 2105/2017.

Conflicts of Interest: The authors declare no conflict of interest. 


\section{Appendix A. List of Fish Species with Sequenced Genomes Currently Available}

Table A1. Detailed overview of fish species with a sequenced genome. Diverse levels of genome assemblies (draft, contig, scaffold, fully assembled genomes to the chromosome level) and numbers of assembly versions are listed together with basic cytogenetic traits (2n, C-value, GC\%).

\begin{tabular}{|c|c|c|c|c|c|c|c|c|}
\hline Species & Order ${ }^{a}$ & Family a & Size (Mb) & $\mathrm{C}^{\mathrm{c} v a l^{\mathrm{b}}}{ }^{\mathrm{b}}$ & $n / 2 n^{\mathrm{c}}$ & Assembly/Type ${ }^{d}$ & GC\% & Notes ${ }^{e}$ \\
\hline Acanthochromis polyacanthus & Ovalentaria & Pomacentridae & 991.585 & 0.94 & - & $1 / \mathrm{S}$ & 41.5 & \\
\hline Amphilophus citrinellus & Cichliformes & Cichlasomat., Heroini & 844.903 & - & $-/ 48$ & $1 / \mathrm{S}$ & 41.4 & \\
\hline Anguilla anguilla & Anguilliformes & Anguillidae & 1018.7 & $1.11-1.67$ & $-/ 38$ & $1 / \mathrm{S}$ & 42.9 & \\
\hline Anguilla japonica & Anguilliformes & Anguillidae & 1288.6 & 1.09 & $-/ 38$ & $1 / \mathrm{S}$ & 38.8 & \\
\hline Anguilla rostrata & Anguilliformes & Anguillidae & 1413.03 & $1.01-1.66$ & $-/ 38$ & $1 / \mathrm{S}$ & 41.0 & \\
\hline Anoplopoma fimbria & Perciform $\times$ Scorpaeniform & Anoplomatidae & 699.326 & $0.71-0.84$ & - & $1 / \mathrm{C}$ & 40.3 & \\
\hline Astyanax mexicanus & Characiformes & Characidae & 1335.24 & - & $25 / 50$ & $1 / \mathrm{Ch}$ & 38.4 & \\
\hline Austrofundulus limnaeus & Cyprinodontiformes & Rivulidae & 866.963 & - & - & $1 / \mathrm{S}$ & 41.1 & \\
\hline Boleophthalmus pectinirostris & Gobiiformes & Gobiid., Oxudercinae & 955.752 & - & $-/ 46$ & $1 / \mathrm{S}$ & 40.1 & \\
\hline Branchiostoma belcheri & Cephalochordata & Branchiostomidae & 426.124 & - & $-/ 36$ & $2 / \mathrm{S}$ & 40.15 & \\
\hline Branchiostoma floridae & Cephalochordata & Branchiostomidae & 521.895 & - & - & $1 / \mathrm{S}$ & 41.8 & \\
\hline Callorhinchus milii & Chimaeriformes & Callorhinchidae & 974.499 & 1.94 & - & $1 / \mathrm{S}$ & 42.6 & \\
\hline Channa argus & Perciformes & Channidae & 615.3 & $0.63-0.77$ & $-/ 48$ & $1 / \mathrm{D}$ & - & \\
\hline Clupea harengus & Clupeiformes & Clupeidae & 807.712 & - & $-/ 50-52$ & $1 / \mathrm{S}$ & 44.5 & \\
\hline Cottus rhenanus & Perciformes & Cottidae & 563.609 & - & - & $1 / \mathrm{S}$ & 36.8 & \\
\hline Cynoglossus semilaevis & Pleuronectiformes & Cynoglossidae & 470.199 & 0.62 C. bilineatus & 22 & $1 / \mathrm{Ch}$ & 41.27 & \\
\hline Cyprinodon nevadensis & Cyprinodontiformes & Cyprinodontidae & 1011.85 & - & $-/ 48$ & $1 / \mathrm{S}$ & & \\
\hline Cyprinodon variegatus & Cyprinodontiformes & Cyprinodontidae & 1035.18 & 1.6 & $-/ 48$ & $1 / \mathrm{S}$ & 39.5 & \\
\hline Cyprinus carpio & Cypriniformes & Cyprinidae & 1713.66 & $1.6-2.0$ & $50 / 100$ & $2 / \mathrm{S}, \mathrm{Ch}$ & med 37.1 & \\
\hline Danio rerio & Cypriniformes & Cyprinidae & 1679.2 & $1.6-2.3$ & $25 / 48$ & $4 / 3 \mathrm{~S}, 1 \mathrm{Chr}$ & med 36.7 & \\
\hline Dicentrarchus labrax & Moroniformes & Moronidae & 675.917 & 0.78 & - & $2 / \mathrm{S}$ & 40.4 & \\
\hline Eptatretus burgeri & Myxiniformes & Myxinidae/Eptatretinae & 2608.38 & 2.98 & $/ 36$ & $1 / \mathrm{S}$ & - & \\
\hline Esox lucius & Esociformes & Esocidae & 904.497 & $0.8-1.4$ & $25 / 50$ & $3 / \mathrm{Ch}$ & 42.2 & $\mathrm{~PB}$ \\
\hline Fundulus heteroclitus & Cyprinodontiformes & Fundulidae & 1021.9 & $1.3-1.5$ & $-/ 48$ & $1 / \mathrm{S}$ & 41.2 & \\
\hline Gadus morhua & Gadiformes & Gadidae & 824.311 & $0.4-0.9$ & $-/ 46$ & $2 / \mathrm{S}$ & 46.3 & 454, I, PB [124] \\
\hline Gasterosteus aculeatus & Perciformes & Cottiodei, Gasterosteid. & 446.611 & $0.6-0.7$ & $-/ 42$ & $2 / \mathrm{S}, \mathrm{Ch}$ & 44.6 & LM [163] \\
\hline Haplochromis burtoni & Perciformes $\times$ Cichliformes & Cichlidae (Afr.) & 831.412 & 0.97 & $-/ 40$ & $1 / \mathrm{S}$ & 41.9 & \\
\hline Hippocampus comes & Syngnathiformes & Syngnathidae & 493.776 & - & - & $1 / \mathrm{S}$ & 43.7 & \\
\hline Ictalurus punctatus & Siluriformes & Ictaluridae & 783.275 & 1.0 & $29 / 58$ & $1 / \mathrm{Ch}$ & 39.8 & PB, I $[164,165]$ \\
\hline Kryptolebias marmoratus & Cyprinodontiformes & Rivulidae & 680.367 & - & $-/ 48$ & $2 / \mathrm{S}$ & med 39.5 & \\
\hline Labeotropheus fuelleborni & Perciformes $\times$ Cichliformes & Cichlidae (Afr.) & 70.8584 & $\overline{-}$ & $\begin{array}{l}-1 / 40 \\
-/ 44\end{array}$ & $1 / \mathrm{S}$ & 42.1 & \\
\hline Labrus bergylta & Labriformes & Labridae & 805.481 & - & - & $1 / \mathrm{S}$ & 40.9 & \\
\hline Larimichthys crocea & Acanthuriformes & Sciaenidae & 678.938 & - & - & $2 / \mathrm{S}$ & med 41.4 & \\
\hline Lates calcarifer & Perciformes & Centropomidae & 668.481 & 0.7 & $-/ 48$ & $2 / \mathrm{S}$ & $\operatorname{med} 40.6$ & \\
\hline Latimeria chalumnae & Ceolacanthiformes & Coelacanthidae & 2860.59 & $2.8-6.6$ & $-/ 48$ & $2 / \mathrm{S}$ & med 42.5 & \\
\hline Lepisosteus oculatus & Lepisosteiformes & Lepisosteidae & 945.878 & 1.4 & $29 / 58$ & $1 / \mathrm{Ch}$ & 40.4 & \\
\hline $\begin{array}{l}\text { Lepisosteus oundusus } \\
\text { Lethenteron camtschaticum }\end{array}$ & Petromyzontiformes & Petromyzontidae & 1030.66 & $\begin{array}{l}1.4 \\
\sim 1.4\end{array}$ & $-/ 144-162$ & $1 / \mathrm{S}$ & 48.1 & \\
\hline Leuciscus waleckii & $\begin{array}{l}\text { Cypriniformes } \\
\text { Cormes }\end{array}$ & Cyprinidae & 752.539 & congeners $1.2-1.5$ & -150 & $1 / \mathrm{S}$ & 37.4 & \\
\hline Leucoraja erinacea & $\begin{array}{l}\text { Rajiformes } \\
\text { Rerment }\end{array}$ & Rajidae & 1555.46 & $3.5-4.6$ & -100 & $1 / \mathrm{C}$ & 40.3 & \\
\hline Maccullochella peelii & Perciformes $x$ & Percichthyidae & 633.241 & 0.83 & - & $1 / \mathrm{s}$ & - & \\
\hline Maylandia zebra & Perciformes $\times$ Cichliformes & Cichlidae (Afr.) & 859.842 & - & - & $2 / \mathrm{S}$ & 41.4 & \\
\hline Mchenga conophoros & Perciformes $\times$ Cichliformes & Cichlidae (Afr.) & 73.4256 & - & - & $1 / \mathrm{S}$ & 41.8 & \\
\hline Megalobrama amblycephala & Cypriniformes & Cyprinidae, Cultrinae & 1116.0 & $1.12-1.35$ & - & $1 / \mathrm{D}$ & 37.3 & {$[166]$} \\
\hline Melanochromis auratus & Perciformes $\times$ Cichliformes & Cichlidae (Afr.) & 68.2386 & - & $-/ 46$ & $1 / \mathrm{S}$ & 41.5 & \\
\hline Miichthys miiuy & Acanthuriformes & Sciaenidae & 619.301 & - & - & $1 / \mathrm{S}$ & 39.3 & \\
\hline Mola mola & Tetraodontiformes & Molidae & 639.452 & $0.8-0.9$ & $-/ 46$ & $1 / \mathrm{S}$ & 41.2 & [167] \\
\hline
\end{tabular}


Table A1. Cont.

\begin{tabular}{|c|c|c|c|c|c|c|c|c|}
\hline Species & Order $^{\mathrm{a}}$ & Family ${ }^{a}$ & Size $(M b)$ & C-val ${ }^{b}$ & $n / 2 n^{\mathrm{c}}$ & Assembly/Type $^{\mathrm{d}}$ & GC\% & Notes ${ }^{e}$ \\
\hline Monopterus albus & Synbranchiformes & Synbranchidae & 684.144 & $0.6-0.9$ & $-/ 24$ & $1 / \mathrm{S}$ & 41.5 & \\
\hline Morone saxatilis & Moroniformes & Moronidae & 585.167 & 0.9 & $-/ 48$ & $1 / \mathrm{S}$ & 40.0 & \\
\hline Neolamprologus brichardi & Perciformes $\times$ Cichliformes & Cichlidae (Afr.) & 847.91 & - & - & $1 / \mathrm{S}$ & 42 & \\
\hline Nothobranchius furzeri & Cyprinodontiformes & Notobranchiidae & 1132.74 & 1.56 & $19 / 38$ & 4/S, Chr & 43,8 & \\
\hline Nothobranchius kuhntae & Cyprinodontiformes & Notobranchiidae & 5.23461 & - & $-/ 38$ & $1 / \mathrm{S}$ & 44.8 & \\
\hline Notothenia coriiceps & Perciformes & Nototheniidae & 636.614 & - & - & $1 / \mathrm{S}$ & 40.8 & \\
\hline Oncorhynchus kisutch & Salmoniformes & Salmonidae & 2369.93 & $2.6-3.0$ & $30 / 60$ & $1 / \mathrm{Ch}$ & 43.6 & \\
\hline Oncorhynchus mykiss & Salmoniformes & Salmonidae & 2179 & $1.9-2.9$ & $29 / 60$ & $2 / \mathrm{Ch}$ & med 43.7 & \\
\hline Oreochromis niloticus & Perciformes $\times$ Cichliformes & Cichlidae (Afr.) & 1009.86 & $0.9-1.2$ & $23 / 44$ & $2 / \mathrm{Ch}$ & med 39.9 & PB, I [ $[168,169$ \\
\hline Oryzias latipes & Beloniformes & Adrianichthyidae & 869.818 & $0.9-1.1$ & $24 / 48$ & $5 / \mathrm{Ch}$ & med 40.8 & \\
\hline Pampus argenteus & Scombriformes & Stromateidae & 350.449 & - & - & $1 / \mathrm{S}$ & 38.2 & \\
\hline Paralichthys olivaceus & Pleuronectiformes & Paralichthyidae & 643.911 & 0.7 & $24 / 46-48$ & $2 / \mathrm{S}, \mathrm{Ch}$ & $\operatorname{med} 42.4$ & \\
\hline Periophthalmodon schlosseri & Gobiiformes & Gobiid., Oxudercinae & 679.761 & 0.96 & - & $1 / \mathrm{S}$ & 40.2 & \\
\hline Periophthalmus magnuspinnatus & Gobiiformes & Gobiid., Oxudercinae & 701.697 & - & - & $1 / \mathrm{S}$ & 40 & \\
\hline Petromyzon marinus & Petromyzontiformes & Petromyzontidae & 885.535 & $1.6-2.4$ & $-/ 168$ & $1 / \mathrm{S}$ & 46.8 & \\
\hline Pimephales promelas & Cypriniformes & Cyprinidae & 1219.33 & 1.1 & $-/ 50$ & $2 / \mathrm{S}$ & med 40.6 & \\
\hline Poecilia formosa & Cyprinodontiformes & Poeciliidae & 748.923 & $0.75-0.97$ & $-/ 46$ & $1 / \mathrm{S}$ & 39.6 & \\
\hline Poecilia latipinna & Cyprinodontiformes & Poeciliidae & 815.145 & $0.9-1.0$ & $-/ 46$ & $1 / \mathrm{S}$ & 40.8 & \\
\hline Poecilia mexicana & Cyprinodontiformes & Poeciliidae & 801.711 & $0.7-1.38$ & $-/ 46$ & $1 / \mathrm{S}$ & 40.7 & \\
\hline Poecilia reticulata & Cyprinodontiformes & Poeciliidae & 731.622 & $0.77-1.0$ & $23 / 46$ & $1 / \mathrm{Ch}$ & 40.3 & \\
\hline Protosalanx hyalocranius & Osmeriformes & Salangidae & 525 & - & - & $1 / \mathrm{D}$ & - & \\
\hline Pseudopleuronectes yokohamae & Pleuronectiformes & Pleuronectidae & 547.831 & 0.67 & $-/ 48$ & $1 / \mathrm{C}$ & 42 & \\
\hline Pundamilia nyererei & Perciformes $\times$ Cichliformes & Cichlidae (Afr.) & 830.133 & - & - & $1 / \mathrm{s}$ & 41.9 & \\
\hline Pygocentrus nattereri & Characiformes & Serrasalmidae & 1285.35 & - & - & $1 / \mathrm{S}$ & 40.6 & \\
\hline Rhamphochromis esox & Perciformes $\times$ Cichliformes & Cichlidae (Afr.) & 71.2951 & - & - & $1 / \mathrm{S}$ & 42.3 & \\
\hline Rhincodon typus & Orectolobiformes & Rhincodontidae & 2931.6 & - & - & $1 / \mathrm{S}$ & 41.8 & \\
\hline Salmo salar & Salmoniformes & Salmonidae & 2966.89 & $3.0-3.3$ & $29 / 60$ & $1 / \mathrm{Ch}$ & 43.9 & PB, I, S [170] \\
\hline Scartelaos histophorus & Gobiiformes & Gobiid., Oxudercinae & 695.009 & - & - & $1 / \mathrm{S}$ & 39.1 & \\
\hline Scleropages formosus & Osteoglossiformes & Osteoglossidae & 777.359 & - & - & 4/S, Chr & med 43.9 & \\
\hline Sebastes aleutianus & Scorpaeniformes & Sebastidae & 899.65 & - & - & $1 / \mathrm{S}$ & 40.9 & \\
\hline Sebastes minor & Scorpaeniformes & Sebastidae & 681.653 & - & - & $1 / \mathrm{S}$ & 40.8 & \\
\hline Sebastes nigrocinctus & Scorpaeniformes & Sebastidae & 746.045 & - & - & $1 / \mathrm{S}$ & 40.8 & \\
\hline Sebastes rubrivinctus & Scorpaeniformes & Sebastidae & 756.297 & - & - & $1 / \mathrm{s}$ & 40.7 & \\
\hline Sebastes steindachneri & Scorpaeniformes & Sebastidae & 648.011 & - & - & $1 / \mathrm{S}$ & 40.7 & \\
\hline Seriola dumerili & Carangiformes & Carangidae & 677.67 & 0.74 & - & $1 / \mathrm{S}$ & 40.9 & \\
\hline Seriola lalandi & Carangiformes & Carangidae & 685 & - & - & $1 / \mathrm{S}$ & & $\mathrm{PB}, \mathrm{I}$ \\
\hline Seriola quinqueradiata & Carangiformes & Carangidae & med 750.45 & 0.83 & - & $2 / \mathrm{S}$ & 40.25 & \\
\hline Sinocyclocheilus anshuiensis & Cypriniformes & Cyprinidae & 1632.72 & - & - & $1 / \mathrm{S}$ & 38 & \\
\hline Sinocyclocheilus grahami & Cypriniformes & Cyprinidae & 1750.29 & 2.35 & $-/ 96$ & $1 / \mathrm{S}$ & 38.7 & \\
\hline Sinocyclocheilus rhinocerous & Cypriniformes & Cyprinidae & 1655.79 & - & - & $1 / \mathrm{S}$ & 38.1 & \\
\hline Squalius pyrenaicus & Cypriniformes & Cyprinidae & 48.1393 & 2.4 & $-/ 50$ & $1 / \mathrm{C}$ & 51.8 & \\
\hline Stegastes partitus & Ovalentaria & Pomacentridae & 800.492 & - & - & $1 / \mathrm{S}$ & 42.1 & \\
\hline Takifugu flavidus & Tetraodontiformes & Tetraodontidae & 378.032 & - & - & $1 / \mathrm{S}$ & 45.6 & \\
\hline Takifugu rubripes & Tetraodontiformes & Tetraodontidae & 391.485 & 0.4 & $22 / 44$ & $1 / \mathrm{Ch}$ & 45.8 & \\
\hline Tetraodon nigroviridis & Tetraodontiformes & Tetraodontidae & 342.403 & $0.35-0.51$ & $21 / 42$ & $7 / \mathrm{S}, \mathrm{Ch}$ & 46.6 & Genoscope \\
\hline Thunnus orientalis & Scombriformes & Scombridae & 684.497 & - & $-/ 48$ & $1 / \mathrm{C}$ & 39.7 & \\
\hline Xiphophorus couchianus & Cyprinodontiformes & Poeciliidae & 708.396 & 0.75 & - & $1 / \mathrm{S}$ & 40.9 & \\
\hline Xiphophorus hellerii & Cyprinodontiformes & Poeciliidae & 733.802 & $0.7-1.0$ & $-/ 48$ & $1 / \mathrm{S}$ & 41.2 & \\
\hline Xiphophorus maculatus & Cyprinodontiformes & Poeciliidae & 729.664 & $0.8-1.0$ & $-/ 48$ & $1 / \mathrm{S}$ & 39.8 & \\
\hline
\end{tabular}

a orders and families mostly based on [22]; ${ }^{\mathrm{b}} \mathrm{c}$-value, based on [12] database; ${ }^{\mathrm{c}} n$ : based on genomic/sequence data, originates from NCBI, $2 n$ based on cytogenetic data [86]; ${ }^{\mathrm{d}}$ number of assemblies currently released and level of assembly $\left(\mathrm{C}=\right.$ contig, $\mathrm{D}=$ draft, $\mathrm{S}=$ scaffold, $\mathrm{Ch}=$ chromosomal level); ${ }^{\mathrm{e}}$ Sequencing methods $(\mathrm{I}=\mathrm{Illumina}, \mathrm{PB}=\mathrm{PacBio}, \mathrm{S}=\mathrm{Sanger})$, linkage map (LM) available. 


\section{References}

1. Bernheim, A. Cytogenomics of cancers: From chromosome to sequence. Mol. Oncol. 2010, 4, 309-322. [CrossRef] [PubMed]

2. Xiang, B.; Leon, A.; Li, M.M.; Iqbal, A.M.; Li, P.; Li, S.; Papenhausen, P.R.; Schwartz, S.; Zhang, X.-X.; Geiersbach, K.B.; et al. Atlas of Cytogenomics in Oncology and Hematology: A Platform-Neutral Clinical Cancer Genomics Database. Cancer Genet. 2012, 205, 420. [CrossRef]

3. McPherson, M.C.; Robinson, C.M.; Gehlen, L.P.; Delany, M.E. Comparative cytogenomics of poultry: Mapping of single gene and repeat loci in the Japanese quail (Coturnix japonica). Chromosome Res. 2014, 22, 71-83. [CrossRef] [PubMed]

4. Barh, D.; Khan, M.S.; Davies, E. PlantOmics: The Omics of Plant Science; Springer: New Delhi, India, 2015; ISBN 978-81-322-2172-2.

5. Kapusta, A.; Suh, A. Evolution of bird genomes-a transposon's-eye view. Ann. N. Y. Acad. Sci. 2017, 1389, $164-185$. [CrossRef] [PubMed]

6. Nakajima, R.T.; Cabral-de-Mello, D.C.; Valente, G.T.; Venere, P.C.; Martins, C. Evolutionary dynamics of rRNA gene clusters in cichlid fish. BMC Evol. Biol. 2012, 12, 198. [CrossRef] [PubMed]

7. Symonová, R.; Majtánová, Z.; Arias-Rodriguez, L.; Mořkovský, L.; Kořínková, T.; Cavin, L.; Pokorná, M.J.; Doležálková, M.; Flajšhans, M.; Normandeau, E.; et al. Genome Compositional Organization in Gars Shows More Similarities to Mammals than to Other Ray-Finned Fish: Cytogenomics of Gars. J. Exp. Zool. B Mol. Dev. Evol. 2017, 328, 607-619. [CrossRef] [PubMed]

8. Symonová, R.; Ocalewicz, K.; Kirtiklis, L.; Delmastro, G.B.; Pelikánová, Š.; Garcia, S.; Kovař́ik, A. Higher-order organisation of extremely amplified, potentially functional and massively methylated $5 \mathrm{~S}$ rDNA in European pikes (Esox sp.). BMC Genom. 2017, 18, 391. [CrossRef] [PubMed]

9. Cioffi, M.B.; Bertollo, L.A.C. Chromosomal distribution and evolution of repetitive DNAs in fish. Genome Dyn. 2012, 7, 197-221. [CrossRef] [PubMed]

10. Betancur-R, R.; Wiley, E.O.; Arratia, G.; Acero, A.; Bailly, N.; Miya, M.; Lecointre, G.; Ortí, G. Phylogenetic classification of bony fishes. BMC Evol. Biol. 2017, 17, 162. [CrossRef] [PubMed]

11. Saha, N.R.; Smith, J.; Amemiya, C.T. Evolution of adaptive immune recognition in jawless vertebrates. Semin. Immunol. 2010, 22, 25-33. [CrossRef] [PubMed]

12. Gregory, T.R. Animal Genome Size Database. Available online: http://genomesize.com (accessed on 9 November 2017).

13. Caputo Barucchi, V.; Giovannotti, M.; Nisi Cerioni, P.; Splendiani, A. Genome Duplication in Early Vertebrates: Insights from Agnathan Cytogenetics. Cytogenet. Genome Res. 2013, 141, 80-89. [CrossRef] [PubMed]

14. Smith, J.J.; Saha, N.R.; Amemiya, C.T. Genome biology of the cyclostomes and insights into the evolutionary biology of vertebrate genomes. Integr. Comp. Biol. 2010, 50, 130-137. [CrossRef] [PubMed]

15. Stingo, V.; Rocco, L. Selachian cytogenetics: A review. Genetica 2001, 111, 329-347. [CrossRef] [PubMed]

16. Rock, J.; Eldridge, M.; Champion, A.; Johnston, P.; Joss, J. Karyotype and nuclear DNA content of the Australian lungfish, Neoceratodus forsteri (Ceratodidae: Dipnoi). Cytogenet. Cell Genet. 1996, 73, 187-189. [CrossRef] [PubMed]

17. Koch, J.; Lüdemann, J.; Spies, R.; Last, M.; Amemiya, C.T.; Burmester, T. Unusual Diversity of Myoglobin Genes in the Lungfish. Mol. Biol. Evol. 2016, 33, 3033-3041. [CrossRef] [PubMed]

18. Bogart, J.P.; Balon, E.K.; Bruton, M.N. The chromosomes of the living coelacanth and their remarkable similarity to those of one of the most ancient frogs. J. Hered. 1994, 85, 322-325. [CrossRef] [PubMed]

19. Andreyushkova, D.A.; Makunin, A.I.; Beklemisheva, V.R.; Romanenko, S.A.; Druzhkova, A.S.; Biltueva, L.B.; Serdyukova, N.A.; Graphodatsky, A.S.; Trifonov, V.A. Next Generation Sequencing of Chromosome-Specific Libraries Sheds Light on Genome Evolution in Paleotetraploid Sterlet (Acipenser ruthenus). Genes 2017, 8, 318. [CrossRef] [PubMed]

20. Romanenko, S.A.; Biltueva, L.S.; Serdyukova, N.A.; Kulemzina, A.I.; Beklemisheva, V.R.; Gladkikh, O.L.; Lemskaya, N.A.; Interesova, E.A.; Korentovich, M.A.; Vorobieva, N.V.; et al. Segmental paleotetraploidy revealed in sterlet (Acipenser ruthenus) genome by chromosome painting. Mol. Cytogenet. 2015, 8, 90. [CrossRef] [PubMed] 
21. Helfman, G.S.; Collette, B.B.; Facey, D.E.; Bowen, B.W. The Diversity of Fishes: Biology, Evolution, and Ecology, 2nd ed.; Wiley-Blackwell: Oxford, UK, 2009; ISBN 978-1-4051-2494-2.

22. Nelson, J.S.; Grande, T.; Wilson, M.V.H. Fishes of the World, 5th ed.; John Wiley \& Sons: Hoboken, NJ, USA, 2016; ISBN 978-1-118-34233-6.

23. Cavin, L. Freshwater Fishes: 250 Million Years of Evolutionary History; ISTE Press/Elsevier: London, UK, 2017.

24. Sallan, L.C. Major issues in the origins of ray-finned fish (Actinopterygii) biodiversity. Biol. Rev. Camb. Philos. Soc. 2014, 89, 950-971. [CrossRef] [PubMed]

25. Majtánová, Z.; Symonová, R.; Arias-Rodriguez, L.; Sallan, L.; Ráb, P. “Holostei versus Halecostomi” Problem: Insight from Cytogenetics of Ancient Nonteleost Actinopterygian Fish, Bowfin Amia calva. J. Exp. Zool. B Mol. Dev. Evol. 2017, 328, 620-628. [CrossRef] [PubMed]

26. Vega, C.G.; Wiens, J.J. Why are there so few fish in the sea? Proc. R. Soc. B Biol. Sci. 2012, 279, $2323-2329$. [CrossRef] [PubMed]

27. Comber, S.C.L.; Smith, C. Polyploidy in fishes: Patterns and processes: Polyploidy in fishes. Biol. J. Linn. Soc. 2004, 82, 431-442. [CrossRef]

28. Smith, E.M.; Gregory, T.R. Patterns of genome size diversity in the ray-finned fishes. Hydrobiologia 2009, 625, 1-25. [CrossRef]

29. Mank, J.E.; Avise, J.C. Phylogenetic conservation of chromosome numbers in Actinopterygiian fishes. Genetica 2006, 127, 321-327. [CrossRef] [PubMed]

30. Francis, W.R.; Wörheide, G. Similar Ratios of Introns to Intergenic Sequence across Animal Genomes. Genome Biol. Evol. 2017, 9, 1582-1598. [CrossRef] [PubMed]

31. Sarropoulou, E.; Fernandes, J.M.O. Comparative genomics in teleost species: Knowledge transfer by linking the genomes of model and non-model fish species. Comp. Biochem. Physiol. Part D Genom. Proteom. 2011, 6, 92-102. [CrossRef] [PubMed]

32. Howe, K.; Clark, M.D.; Torroja, C.F.; Torrance, J.; Berthelot, C.; Muffato, M.; Collins, J.E.; Humphray, S.; McLaren, K.; Matthews, L.; et al. The zebrafish reference genome sequence and its relationship to the human genome. Nature 2013, 496, 498-503. [CrossRef] [PubMed]

33. Santoriello, C.; Zon, L.I. Hooked! Modeling human disease in zebrafish. J. Clin. Investig. 2012, 122, $2337-2343$. [CrossRef] [PubMed]

34. Gibbons, J.G.; Branco, A.T.; Godinho, S.A.; Yu, S.; Lemos, B. Concerted copy number variation balances ribosomal DNA dosage in human and mouse genomes. Proc. Natl. Acad. Sci. USA 2015, 112, 2485-2490. [CrossRef] [PubMed]

35. Symonová, R.; Majtánová, Z.; Sember, A.; Staaks, G.B.; Bohlen, J.; Freyhof, J.; Rábová, M.; Ráb, P. Genome differentiation in a species pair of coregonine fishes: An extremely rapid speciation driven by stress-activated retrotransposons mediating extensive ribosomal DNA multiplications. BMC Evol. Biol. 2013, 13, 42. [CrossRef] [PubMed]

36. Xu, B.; Li, H.; Perry, J.M.; Singh, V.P.; Unruh, J.; Yu, Z.; Zakari, M.; McDowell, W.; Li, L.; Gerton, J.L. Ribosomal DNA copy number loss and sequence variation in cancer. PLOS Genet. 2017, 13, e1006771. [CrossRef] [PubMed]

37. Cioffi, M.B.; Martins, C.; Bertollo, L.A.C. Chromosome spreading of associated transposable elements and ribosomal DNA in the fish Erythrinus erythrinus. Implications for genome change and karyoevolution in fish. BMC Evol. Biol. 2010, 10, 271. [CrossRef] [PubMed]

38. Animal rDNA Database. Available online: www.animalrdnadatabase.com (accessed on 9 November 2017).

39. Sochorová, J.; Garcia, S.; Gálvez, F.; Symonová, R.; Kovařík, A. Evolutionary trends in animal ribosomal DNA loci: Introduction to a new online database. Chromosoma 2017. [CrossRef] [PubMed]

40. Reed, K.M.; Phillips, R.B. Structure and organization of the rDNA intergenic spacer in lake trout (Salvelinus namaycush). Chromosome Res. Int. J. Mol. Supramol. Evol. Asp. Chromosome Biol. 2000, 8, 5-16. [CrossRef]

41. Reed, K.M.; Hackett, J.D.; Phillips, R.B. Comparative analysis of intra-individual and inter-species DNA sequence variation in salmonid ribosomal DNA cistrons. Gene 2000, 249, 115-125. [CrossRef]

42. Mazzuchelli, J.; Kocher, T.D.; Yang, F.; Martins, C. Integrating cytogenetics and genomics in comparative evolutionary studies of cichlid fish. BMC Genom. 2012, 13, 463. [CrossRef] [PubMed]

43. Chitramuthu, B. Modeling Human Disease and Development in Zebrafish. Hum. Genet. Embryol. 2013, 3, e108. [CrossRef] 
44. Liu, S.; Leach, S.D. Zebrafish Models for Cancer. Annu. Rev. Pathol. Mech. Dis. 2011, 6, 71-93. [CrossRef] [PubMed]

45. Schartl, M. Beyond the zebrafish: Diverse fish species for modeling human disease. Dis. Model. Mech. 2014, 7, 181-192. [CrossRef] [PubMed]

46. Kari, G.; Rodeck, U.; Dicker, A.P. Zebrafish: An emerging model system for human disease and drug discovery. Clin. Pharmacol. Ther. 2007, 82, 70-80. [CrossRef] [PubMed]

47. Amores, A.; Force, A.; Yan, Y.L.; Joly, L.; Amemiya, C.; Fritz, A.; Ho, R.K.; Langeland, J.; Prince, V.; Wang, Y.L.; et al. Zebrafish HOX clusters and vertebrate genome evolution. Science 1998, 282, 1711-1714. [CrossRef] [PubMed]

48. Braasch, I.; Postlethwait, J.H. Polyploidy in Fish and the Teleost Genome Duplication. In Polyploidy and Genome Evolution; Soltis, P.S., Soltis, D.E., Eds.; Springer: Berlin/Heidelberg, Germany, 2012; pp. 341-383. ISBN 978-3-642-31441-4.

49. Meyer, A.; Schartl, M. Gene and genome duplications in vertebrates: The one-to-four (-to-eight in fish) rule and the evolution of novel gene functions. Curr. Opin. Cell Biol. 1999, 11, 699-704. [CrossRef]

50. Postlethwait, J.H.; Woods, I.G.; Ngo-Hazelett, P.; Yan, Y.L.; Kelly, P.D.; Chu, F.; Huang, H.; Hill-Force, A.; Talbot, W.S. Zebrafish comparative genomics and the origins of vertebrate chromosomes. Genome Res. 2000, 10, 1890-1902. [CrossRef] [PubMed]

51. Ceol, C.J.; Houvras, Y.; Jane-Valbuena, J.; Bilodeau, S.; Orlando, D.A.; Battisti, V.; Fritsch, L.; Lin, W.M.; Hollmann, T.J.; Ferré, F.; et al. The histone methyltransferase SETDB1 is recurrently amplified in melanoma and accelerates its onset. Nature 2011, 471, 513-517. [CrossRef] [PubMed]

52. Golzio, C.; Willer, J.; Talkowski, M.E.; Oh, E.C.; Taniguchi, Y.; Jacquemont, S.; Reymond, A.; Sun, M.; Sawa, A.; Gusella, J.F.; et al. KCTD13 is a major driver of mirrored neuroanatomical phenotypes of the 16p11.2 copy number variant. Nature 2012, 485, 363-367. [CrossRef] [PubMed]

53. Panizzi, J.R.; Becker-Heck, A.; Castleman, V.H.; Al-Mutairi, D.A.; Liu, Y.; Loges, N.T.; Pathak, N.; Austin-Tse, C.; Sheridan, E.; Schmidts, M.; et al. CCDC103 mutations cause primary ciliary dyskinesia by disrupting assembly of ciliary dynein arms. Nat. Genet. 2012, 44, 714-719. [CrossRef] [PubMed]

54. Roscioli, T.; Kamsteeg, E.-J.; Buysse, K.; Maystadt, I.; van Reeuwijk, J.; van den Elzen, C.; van Beusekom, E.; Riemersma, M.; Pfundt, R.; Vissers, L.E.L.M.; et al. Mutations in ISPD cause Walker-Warburg syndrome and defective glycosylation of $\alpha$-dystroglycan. Nat. Genet. 2012, 44, 581-585. [CrossRef] [PubMed]

55. Patton, E.E.; Widlund, H.R.; Kutok, J.L.; Kopani, K.R.; Amatruda, J.F.; Murphey, R.D.; Berghmans, S.; Mayhall, E.A.; Traver, D.; Fletcher, C.D.M.; et al. BRAF mutations are sufficient to promote nevi formation and cooperate with p53 in the genesis of melanoma. Curr. Biol. 2005, 15, 249-254. [CrossRef] [PubMed]

56. Wittbrodt, J.; Shima, A.; Schartl, M. Medaka-A model organism from the far East. Nat. Rev. Genet. 2002, 3, 53-64. [CrossRef] [PubMed]

57. Albertson, R.C.; Cresko, W.; Detrich, H.W.; Postlethwait, J.H. Evolutionary mutant models for human disease. Trends Genet. 2009, 25, 74-81. [CrossRef] [PubMed]

58. McGaugh, S.E.; Gross, J.B.; Aken, B.; Blin, M.; Borowsky, R.; Chalopin, D.; Hinaux, H.; Jeffery, W.R.; Keene, A.; Ma, L.; et al. The cavefish genome reveals candidate genes for eye loss. Nat. Commun. 2014, 5, 5307. [CrossRef] [PubMed]

59. Protas, M.E.; Hersey, C.; Kochanek, D.; Zhou, Y.; Wilkens, H.; Jeffery, W.R.; Zon, L.I.; Borowsky, R.; Tabin, C.J. Genetic analysis of cavefish reveals molecular convergence in the evolution of albinism. Nat. Genet. 2006, 38, 107-111. [CrossRef] [PubMed]

60. Terzibasi, E.; Valenzano, D.R.; Cellerino, A. The short-lived fish Nothobranchius furzeri as a new model system for aging studies. Exp. Gerontol. 2007, 42, 81-89. [CrossRef] [PubMed]

61. Hárosi, F.I.; von Herbing, I.H.; Van Keuren, J.R. Sickling of anoxic red blood cells in fish. Biol. Bull. 1998, 195, 5-11. [CrossRef] [PubMed]

62. Meierjohann, S.; Schartl, M. From Mendelian to molecular genetics: The Xiphophorus melanoma model. Trends Genet. 2006, 22, 654-661. [CrossRef] [PubMed]

63. Schartl, M.; Walter, R.B.; Shen, Y.; Garcia, T.; Catchen, J.; Amores, A.; Braasch, I.; Chalopin, D.; Volff, J.-N.; Lesch, K.-P.; et al. The genome of the platyfish, Xiphophorus maculatus, provides insights into evolutionary adaptation and several complex traits. Nat. Genet. 2013, 45, 567-572. [CrossRef] [PubMed] 
64. Schmale, M.C.; Hensley, G.T.; Udey, L.R. Neurofibromatosis in the bicolor damselfish (Pomacentrus partitus) as a model of von Recklinghausen neurofibromatosis. Ann. N. Y. Acad. Sci. 1986, 486, 386-402. [CrossRef] [PubMed]

65. Williams, D.E. The rainbow trout liver cancer model: Response to environmental chemicals and studies on promotion and chemoprevention. Comp. Biochem. Physiol. Part C Toxicol. Pharmacol. 2012, 155, 121-127. [CrossRef] [PubMed]

66. Burnett, K.G.; Bain, L.J.; Baldwin, W.S.; Callard, G.V.; Cohen, S.; Di Giulio, R.T.; Evans, D.H.; Gómez-Chiarri, M.; Hahn, M.E.; Hoover, C.A.; et al. Fundulus as the premier teleost model in environmental biology: Opportunities for new insights using genomics. Comp. Biochem. Physiol. Part D Genom. Proteom. 2007, 2, 257-286. [CrossRef] [PubMed]

67. Lampert, K.; Schartl, M. The origin and evolution of a unisexual hybrid: Poecilia formosa. Philos. Trans. R. Soc. B Biol. Sci. 2008, 363, 2901-2909. [CrossRef] [PubMed]

68. Schartl, M.; Nanda, I.; Schlupp, I.; Wilde, B.; Epplen, J.T.; Schmid, M.; Parzefall, J. Incorporation of subgenomic amounts of DNA as compensation for mutational load in a gynogenetic fish. Nature 1995, 373, 68-71. [CrossRef]

69. Schartl, A.; Hornung, U.; Nanda, I.; Wacker, R.; Müller-Hermelink, H.K.; Schlupp, I.; Parzefall, J.; Schmid, M.; Schartl, M. Susceptibility to the development of pigment cell tumors in a clone of the Amazon molly, Poecilia formosa, introduced through a microchromosome. Cancer Res. 1997, 57, 2993-3000. [PubMed]

70. Tobler, M.; Schlupp, I. Parasites in sexual and asexual mollies (Poecilia, Poeciliidae, Teleostei): A case for the Red Queen? Biol. Lett. 2005, 1, 166-168. [CrossRef] [PubMed]

71. Woodhead, A.D.; Setlow, R.B.; Pond, V. The Amazon molly, Poecilia formosa, as a test animal in carcinogenicity studies: Chronic exposures to physical agents. Natl. Cancer Inst. Monogr. 1984, 65, 45-52. [PubMed]

72. Scahill, C.M.; Digby, Z.; Sealy, I.M.; Wojciechowska, S.; White, R.J.; Collins, J.E.; Stemple, D.L.; Bartke, T.; Mathers, M.E.; Patton, E.E.; et al. Loss of the chromatin modifier Kdm2aa causes BrafV600E-independent spontaneous melanoma in zebrafish. PLoS Genet. 2017, 13, e1006959. [CrossRef] [PubMed]

73. Cossins, A.R.; Crawford, D.L. Fish as models for environmental genomics. Nat. Rev. Genet. 2005, 6, 324-333. [CrossRef] [PubMed]

74. Aquaculture Genomics, Genetics and Breeding Workshop; Abdelrahman, H.; ElHady, M.; Alcivar-Warren, A.; Allen, S.; Al-Tobasei, R.; Bao, L.; Beck, B.; Blackburn, H.; Bosworth, B.; et al. Aquaculture genomics, genetics and breeding in the United States: Current status, challenges and priorities for future research. BMC Genom. 2017, 18, 191. [CrossRef]

75. Kobayashi, T. Genome Instability of Repetitive Sequence: Lesson from the Ribosomal RNA Gene Repeat. In DNA Replication, Recombination and Repair; Hanaoka, F., Sugasawa, K., Eds.; Springer: Tokyo, Japan, 2016; pp. 235-247. ISBN 978-4-431-55871-2.

76. Wang, M.; Lemos, B. Ribosomal DNA copy number amplification and loss in human cancers is linked to tumor genetic context, nucleolus activity and proliferation. PLoS Genet. 2017, 13, e1006994. [CrossRef] [PubMed]

77. Boisvert, F.-M.; van Koningsbruggen, S.; Navascués, J.; Lamond, A.I. The multifunctional nucleolus. Nat. Rev. Mol. Cell Biol. 2007, 8, 574-585. [CrossRef] [PubMed]

78. Guetg, C.; Santoro, R. Formation of nuclear heterochromatin: The nucleolar point of view. Epigenetics 2012, 7, 811-814. [CrossRef] [PubMed]

79. Makunin, A.I.; Dementyeva, P.V.; Graphodatsky, A.S.; Volobouev, V.T.; Kukekova, A.V.; Trifonov, V.A. Genes on B chromosomes of vertebrates. Mol. Cytogenet. 2014, 7, 99. [CrossRef] [PubMed]

80. Terencio, M.L.; Schneider, C.H.; Gross, M.C.; do Carmo, E.J.; Nogaroto, V.; de Almeida, M.C.; Artoni, R.F.; Vicari, M.R.; Feldberg, E. Repetitive sequences: The hidden diversity of heterochromatin in prochilodontid fish. Comp. Cytogenet. 2015, 9, 465-481. [CrossRef] [PubMed]

81. Tsekrekou, M.; Stratigi, K.; Chatzinikolaou, G. The Nucleolus: In Genome Maintenance and Repair. Int. J. Mol. Sci. 2017, 18, 1411. [CrossRef] [PubMed]

82. Braasch, I.; Gehrke, A.R.; Smith, J.J.; Kawasaki, K.; Manousaki, T.; Pasquier, J.; Amores, A.; Desvignes, T.; Batzel, P.; Catchen, J.; et al. The spotted gar genome illuminates vertebrate evolution and facilitates human-teleost comparisons. Nat. Genet. 2016, 48, 427-437. [CrossRef] [PubMed] 
83. Dion- Côté, A.-M.; Symonová, R.; Ráb, P.; Bernatchez, L. Reproductive isolation in a nascent species pair is associated with aneuploidy in hybrid offspring. Proc. R. Soc. B Biol. Sci. 2015, 282, 20142862. [CrossRef] [PubMed]

84. Clark, M.S. Genomics and Mapping of Teleostei (Bony Fish). Comp. Funct. Genom. 2003, 4, 182-193. [CrossRef] [PubMed]

85. Carvalho, G.R.; Hauser, L.; Martinsohn, J.; Naish, K. Fish, genes and genomes: Contributions to ecology, evolution and management. J. Fish Biol. 2016, 89, 2471-2478. [CrossRef] [PubMed]

86. Arai, R. Fish Karyotypes; Springer: Tokyo, Japan, 2011; ISBN 978-4-431-53876-9.

87. Majtánová, Z.; Choleva, L.; Symonová, R.; Ráb, P.; Kotusz, J.; Pekárik, L.; Janko, K. Asexual Reproduction Does Not Apparently Increase the Rate of Chromosomal Evolution: Karyotype Stability in Diploid and Triploid Clonal Hybrid Fish (Cobitis, Cypriniformes, Teleostei). PLoS ONE 2016, 11, e0146872. [CrossRef] [PubMed]

88. Rampin, M.; Bi, K.; Bogart, J.P.; Collares-Pereira, M.J. Identifying parental chromosomes and genomic rearrangements in animal hybrid complexes of species with small genome size using Genomic In Situ Hybridization (GISH). Comp. Cytogenet. 2012, 6, 287-300. [CrossRef] [PubMed]

89. Havelka, M.; Bytyutskyy, D.; Symonová, R.; Ráb, P.; Flajšhans, M. The second highest chromosome count among vertebrates is observed in cultured sturgeon and is associated with genome plasticity. Genet. Sel. Evol. 2016, 48, 12. [CrossRef] [PubMed]

90. Jaillon, O.; Aury, J.-M.; Brunet, F.; Petit, J.-L.; Stange-Thomann, N.; Mauceli, E.; Bouneau, L.; Fischer, C.; Ozouf-Costaz, C.; Bernot, A.; et al. Genome duplication in the teleost fish Tetraodon nigroviridis reveals the early vertebrate proto-karyotype. Nature 2004, 431, 946-957. [CrossRef] [PubMed]

91. Roest Crollius, H.; Weissenbach, J. Fish genomics and biology. Genome Res. 2005, 15, 1675-1682. [CrossRef] [PubMed]

92. Phillips, R.B.; Amores, A.; Morasch, M.R.; Wilson, C.; Postlethwait, J.H. Assignment of zebrafish genetic linkage groups to chromosomes. Cytogenet. Genome Res. 2006, 114, 155-162. [CrossRef] [PubMed]

93. Phillips, R.B.; Nichols, K.M.; DeKoning, J.J.; Morasch, M.R.; Keatley, K.A.; Rexroad, C.; Gahr, S.A.; Danzmann, R.G.; Drew, R.E.; Thorgaard, G.H. Assignment of rainbow trout linkage groups to specific chromosomes. Genetics 2006, 174, 1661-1670. [CrossRef] [PubMed]

94. Phillips, R.B.; Keatley, K.A.; Morasch, M.R.; Ventura, A.B.; Lubieniecki, K.P.; Koop, B.F.; Danzmann, R.G.; Davidson, W.S. Assignment of Atlantic salmon (Salmo salar) linkage groups to specific chromosomes: Conservation of large syntenic blocks corresponding to whole chromosome arms in rainbow trout (Oncorhynchus mykiss). BMC Genet. 2009, 10, 46. [CrossRef] [PubMed]

95. Guyon, R.; Rakotomanga, M.; Azzouzi, N.; Coutanceau, J.P.; Bonillo, C.; D'Cotta, H.; Pepey, E.; Soler, L.; Rodier-Goud, M.; D'Hont, A.; et al. A high-resolution map of the Nile Tilapia genome: A resource for studying cichlids and other percomorphs. BMC Genom. 2012, 13, 222. [CrossRef] [PubMed]

96. Dion-Côté, A.-M.; Symonová, R.; Lamaze, F.C.; Pelikánová, Š.; Ráb, P.; Bernatchez, L. Standing chromosomal variation in Lake Whitefish species pairs: The role of historical contingency and relevance for speciation. Mol. Ecol. 2017, 26, 178-192. [CrossRef] [PubMed]

97. Rondeau, E.B.; Minkley, D.R.; Leong, J.S.; Messmer, A.M.; Jantzen, J.R.; von Schalburg, K.R.; Lemon, C.; Bird, N.H.; Koop, B.F. The genome and linkage map of the northern pike (Esox lucius): Conserved synteny revealed between the salmonid sister group and the Neoteleostei. PLoS ONE 2014, 9, e102089. [CrossRef] [PubMed]

98. Sutherland, B.J.G.; Gosselin, T.; Normandeau, E.; Lamothe, M.; Isabel, N.; Audet, C.; Bernatchez, L. Salmonid Chromosome Evolution as Revealed by a Novel Method for Comparing RADseq Linkage Maps. Genome Biol. Evol. 2016, 8, 3600-3617. [CrossRef] [PubMed]

99. Symonová, R.; Sutherland, B.J.G.; Bernatchez, L. Residually tetrasomic sites in Coregonus clupeaformis. Under preparation.

100. Cozzi, P.; Milanesi, L.; Bernardi, G. Segmenting the Human Genome into Isochores. Evol. Bioinform. 2015, 11, 253-261. [CrossRef] [PubMed]

101. Bernardi, G. Structural and Evolutionary Genomics: Natural Selection in Genome Evolution; New Comprehensive Biochemistry; Elsevier: Amsterdam, The Netherlands, 2004; ISBN 978-0-444-51255-0. 
102. Daniel-Silva, M.F.Z.; Almeida-Toledo, L.F. Chromosome evolution in fish: BrdU replication patterns demonstrate chromosome homeologies in two species of the genus Astyanax. Cytogenet. Genome Res. 2005, 109, 497-501. [CrossRef] [PubMed]

103. Zerbino, D.R.; Achuthan, P.; Akanni, W.; Amode, M.R.; Barrell, D.; Bhai, J.; Billis, K.; Cummins, C.; Gall, A.; Girón, C.G.; et al. Ensembl 2018. Nucleic Acids Res. 2018, 46, D754-D761. [CrossRef] [PubMed]

104. Cioffi, M.B.; Yano, C.F.; Sember, A.; Bertollo, L.A.C. Chromosomal Evolution in Lower Vertebrates: Sex Chromosomes in Neotropical Fishes. Genes 2017, 8, 258. [CrossRef] [PubMed]

105. Cioffi, M.B.; Franco, W.; Ferreira, R.; Carlos Bertollo, L.A. Chromosomes as Tools for Discovering Biodiversity-The Case of Erythrinidae Fish Family. In Recent Trends in Cytogenetic Studies-Methodologies and Applications; Tirunilai, P., Ed.; InTech: Rijeka, Croatia, 2012; ISBN 978-953-51-0178-9.

106. Glasauer, S.M.K.; Neuhauss, S.C.F. Whole-genome duplication in teleost fishes and its evolutionary consequences. Mol. Genet. Genom. 2014, 289, 1045-1060. [CrossRef] [PubMed]

107. Mable, B.; Alexandrou, M.; Taylor, M. Genome duplication in amphibians and fish: An extended synthesis. J. Zool. 2011, 284, 151-182. [CrossRef]

108. Symonová, R.; Havelka, M.; Amemiya, C.T.; Howell, W.M.; Kořínková, T.; Flajšhans, M.; Gela, D.; Ráb, P. Molecular cytogenetic differentiation of paralogs of HOX paralogs in duplicated and re-diploidized genome of the North American paddlefish (Polyodon spathula). BMC Genet. 2017, 18, 19. [CrossRef] [PubMed]

109. Nagpure, N.S.; Rashid, I.; Pathak, A.K.; Singh, M.; Singh, S.P.; Sarkar, U.K. FBIS: A regional DNA barcode archival and analysis system for Indian fishes. Bioinformation 2012, 8, 483-488. [CrossRef] [PubMed]

110. Nagpure, N.S.; Rashid, I.; Pathak, A.K.; Singh, M.; Pati, R.; Singh, S.P.; Sarkar, U.K. FMiR: A Curated Resource of Mitochondrial DNA Information for Fish. PLoS ONE 2015, 10, e0136711. [CrossRef] [PubMed]

111. Nagpure, N.S.; Rashid, I.; Pati, R.; Pathak, A.K.; Singh, M.; Singh, S.P.; Sarkar, U.K. FishMicrosat: A microsatellite database of commercially important fishes and shellfishes of the Indian subcontinent. BMC Genom. 2013, 14, 630. [CrossRef] [PubMed]

112. Avvaru, A.K.; Saxena, S.; Sowpati, D.T.; Mishra, R.K. MSDB: A Comprehensive Database of Simple Sequence Repeats. Genome Biol. Evol. 2017, 9, 1797-1802. [CrossRef] [PubMed]

113. Nagpure, N.S.; Pathak, A.K.; Pati, R.; Rashid, I.; Sharma, J.; Singh, S.P.; Singh, M.; Sarkar, U.K.; Kushwaha, B.; Kumar, R.; et al. Fish Karyome version 2.1: A chromosome database of fishes and other aquatic organisms. Database 2016, 2016, baw012. [CrossRef] [PubMed]

114. Froese, R.; Pauly, D. FishBase. World Wide Web Electronic Publication. 2017. Available online: www.fishbase.org (accessed on 9 November 2017).

115. Bhartiya, D.; Maini, J.; Sharma, M.; Joshi, P.; Laddha, S.V.; Jalali, S.; Patowary, A.; Purkanti, R.; Lalwani, M.; Singh, A.R.; et al. FishMap Zv8 update-A genomic regulatory map of zebrafish. Zebrafish 2010, 7, 179-180. [CrossRef] [PubMed]

116. Amores, A.; Postlethwait, J.H. Banded Chromosomes and the Zebrafish Karyotype. In Methods in Cell Biology; Elsevier: Amsterdam, The Netherlands, 1998; Volume 60, pp. 323-338. ISBN 978-0-12-544162-9.

117. Gornung, E.; De Innocentiis, S.; Annesi, F.; Sola, L. Zebrafish $5 S$ rRNA genes map to the long arms of chromosome 3. Chromosome Res. Int. J. Mol. Supramol. Evol. Asp. Chromosome Biol. 2000, 8, 362. [CrossRef]

118. Phillips, R.B.; Reed, K.M. Localization of repetitive DNAs to zebrafish (Danio rerio) chromosomes by fluorescence in situ hybridization (FISH). Chromosome Res. Int. J. Mol. Supramol. Evol. Asp. Chromosome Biol. 2000, 8, 27-35. [CrossRef]

119. Sola, L.; Gornung, E. Classical and molecular cytogenetics of the zebrafish, Danio rerio (Cyprinidae, Cypriniformes): An overview. Genetica 2001, 111, 397-412. [CrossRef] [PubMed]

120. National Center for Biotechnology Information (NCBI). Genome Browser. Available online: www.ncbi.nlm. nih.gov/genome/browse (accessed on 9 November 2017).

121. Personal Webpage of Radka Symonová. Available online: http://lide.uhk.cz/Symonra1 (accessed on 9 November 2017).

122. Kitts, P.A.; Church, D.M.; Thibaud-Nissen, F.; Choi, J.; Hem, V.; Sapojnikov, V.; Smith, R.G.; Tatusova, T.; Xiang, C.; Zherikov, A.; et al. Assembly: A resource for assembled genomes at NCBI. Nucleic Acids Res. 2016, 44, D73-D80. [CrossRef] [PubMed]

123. European Nucleotide Archive (ENA). Genome Assembly Database. Available online: www.ebi.ac.uk/ena/ browse/genome-assembly-database (accessed on 9 November 2017). 
124. Tørresen, O.K.; Star, B.; Jentoft, S.; Reinar, W.B.; Grove, H.; Miller, J.R.; Walenz, B.P.; Knight, J.; Ekholm, J.M.; Peluso, P.; et al. An improved genome assembly uncovers prolific tandem repeats in Atlantic cod. BMC Genom. 2017, 18, 95. [CrossRef] [PubMed]

125. Malmstrøm, M.; Matschiner, M.; Tørresen, O.K.; Jakobsen, K.S.; Jentoft, S. Whole genome sequencing data and de novo draft assemblies for 66 teleost species. Sci. Data 2017, 4, 160132. [CrossRef] [PubMed]

126. Koepfli, K.-P.; Paten, B. Genome 10K Community of Scientists; O’Brien, S.J. The Genome 10K Project: A way forward. Annu. Rev. Anim. Biosci. 2015, 3, 57-111. [CrossRef] [PubMed]

127. Pasquier, J.; Cabau, C.; Nguyen, T.; Jouanno, E.; Severac, D.; Braasch, I.; Journot, L.; Pontarotti, P.; Klopp, C.; Postlethwait, J.H.; et al. Gene evolution and gene expression after whole genome duplication in fish: The PhyloFish database. BMC Genom. 2016, 17, 368. [CrossRef] [PubMed]

128. China National Genebank. FishT1K. Available online: https://db.cngb.org/fisht1k/status (accessed on 9 November 2017).

129. Garamszegi, L. Z. Modern Phylogenetic Comparative Methods and Their Application in Evolutionary Biology: Concepts and Practice; Springer: Berlin, Germany, 2014; ISBN 978-3-662-43550-2.

130. Hardie, D.C.; Hebert, P.D.N. The nucleotypic effects of cellular DNA content in cartilaginous and ray-finned fishes. Genome 2003, 46, 683-706. [CrossRef] [PubMed]

131. Lefébure, T.; Morvan, C.; Malard, F.; François, C.; Konecny-Dupré, L.; Guéguen, L.; Weiss-Gayet, M.; Seguin-Orlando, A.; Ermini, L.; Sarkissian, C.D.; et al. Less effective selection leads to larger genomes. Genome Res. 2017, 27, 1016-1028. [CrossRef] [PubMed]

132. Gregory, T.R.; Witt, J.D.S. Population size and genome size in fishes: A closer look. Genome 2008, 51, 309-313. [CrossRef] [PubMed]

133. Elliott, T.A.; Gregory, T.R. Do larger genomes contain more diverse transposable elements? BMC Evol. Biol. 2015, 15, 69. [CrossRef] [PubMed]

134. Tarallo, A.; Angelini, C.; Sanges, R.; Yagi, M.; Agnisola, C.; D’Onofrio, G. On the genome base composition of teleosts: The effect of environment and lifestyle. BMC Genom. 2016, 17, 173. [CrossRef] [PubMed]

135. Hardie, D.C.; Hebert, P.D. Genome-size evolution in fishes. Can. J. Fish. Aquat. Sci. 2004, 61, 1636-1646. [CrossRef]

136. Yi, S.; Streelman, J.T. Genome size is negatively correlated with effective population size in ray-finned fish. Trends Genet. 2005, 21, 643-646. [CrossRef] [PubMed]

137. Vervoort, A. Tetraploidy in Protopterus (Dipnoi). Experientia 1980, 36, 294-296. [CrossRef]

138. Paim, F.G.; da Hora Almeida, L.A.; de Mell Affonso, P.R.A.; Sobrinho-Scudeler, P.E.; Oliveira, C.; Diniz, D. Chromosomal stasis in distinct families of marine Percomorpharia from South Atlantic. Comp. Cytogenet. 2017, 11, 299-307. [CrossRef] [PubMed]

139. Camacho, J.P.M.; Sharbel, T.F.; Beukeboom, L.W. B-chromosome evolution. Philos. Trans. R. Soc. B Biol. Sci. 2000, 355, 163-178. [CrossRef] [PubMed]

140. Valente, G.T.; Nakajima, R.T.; Fantinatti, B.E.A.; Marques, D.F.; Almeida, R.O.; Simões, R.P.; Martins, C. B chromosomes: From cytogenetics to systems biology. Chromosoma 2017, 126, 73-81. [CrossRef] [PubMed]

141. Anderson, J.L.; Rodríguez Marí, A.; Braasch, I.; Amores, A.; Hohenlohe, P.; Batzel, P.; Postlethwait, J.H. Multiple sex-associated regions and a putative sex chromosome in zebrafish revealed by RAD mapping and population genomics. PLoS ONE 2012, 7, e40701. [CrossRef] [PubMed]

142. Bradley, K.M.; Breyer, J.P.; Melville, D.B.; Broman, K.W.; Knapik, E.W.; Smith, J.R. An SNP-Based Linkage Map for Zebrafish Reveals Sex Determination Loci. G3 2011, 1, 3-9. [CrossRef] [PubMed]

143. Nagabhushana, A.; Mishra, R.K. Finding clues to the riddle of sex determination in zebrafish. J. Biosci. 2016, 41, 145-155. [CrossRef] [PubMed]

144. Matsuda, M.; Nagahama, Y.; Shinomiya, A.; Sato, T.; Matsuda, C.; Kobayashi, T.; Morrey, C.E.; Shibata, N.; Asakawa, S.; Shimizu, N.; et al. DMY is a Y-specific DM-domain gene required for male development in the Medaka fish. Nature 2002, 417, 559-563. [CrossRef] [PubMed]

145. De Andrade Silva, D.M.Z.; Utsunomia, R.; Ruiz-Ruano, F.J.; Daniel, S.N.; Porto-Foresti, F.; Hashimoto, D.T.; Oliveira, C.; Camacho, J.P.M.; Foresti, F. High-throughput analysis unveils a highly shared satellite DNA library among three species of fish genus Astyanax. Sci. Rep. 2017, 7, 12726. [CrossRef] [PubMed]

146. Ruiz-Estévez, M.; López-León, M.D.; Cabrero, J.; Camacho, J.P.M. B-chromosome ribosomal DNA is functional in the grasshopper Eyprepocnemis plorans. PLoS ONE 2012, 7, e36600. [CrossRef] [PubMed]

147. Utsunomia, R.; de Andrade Silva, D.M.Z.; Ruiz-Ruano, F.J.; Araya-Jaime, C.; Pansonato-Alves, J.C.; Scacchetti, P.C.; Hashimoto, D.T.; Oliveira, C.; Trifonov, V.A.; Porto-Foresti, F.; et al. Uncovering the 
Ancestry of B Chromosomes in Moenkhausia sanctaefilomenae (Teleostei, Characidae). PLoS ONE 2016, 11, e0150573. [CrossRef] [PubMed]

148. Lamatsch, D.K.; Trifonov, V.; Schories, S.; Epplen, J. T.; Schmid, M.; Schartl, M. Isolation of a cancer-associated microchromosome in the sperm-dependent parthenogen Poecilia formosa. Cytogenet. Genome Res. 2011, 135, 135-142. [CrossRef] [PubMed]

149. Schmid, M.; Ziegler, C.G.; Steinlein, C.; Nanda, I.; Schartl, M. Cytogenetics of the bleak (Alburnus alburnus), with special emphasis on the B chromosomes. Chromosome Res. Int. J. Mol. Supramol. Evol. Asp. Chromosome Biol. 2006, 14, 231-242. [CrossRef] [PubMed]

150. Takagui, F.H.; Dias, A.L.; Birindelli, J.L.O.; Swarça, A.C.; da Rosa, R.; Lui, R.L.; Fenocchio, A.S.; Giuliano-Caetano, L. First report of B chromosomes in three neotropical thorny catfishes (Siluriformes, Doradidae). Comp. Cytogenet. 2017, 11, 55-64. [CrossRef] [PubMed]

151. Jones, R.N.; Diez, M. The B chromosome database. Cytog. Gen. Res. 2004, 106, 149-150. [CrossRef] [PubMed]

152. D'Ambrosio, U.; Alonso-Lifante, M.P.; Barros, K.; Kovařík, A.; Mas de Xaxars, G.; Garcia, S. B-chrom: A database on B-chromosomes of plants, animals and fungi. New Phytol. 2017, 216, 635-642. [CrossRef] [PubMed]

153. Grummt, I. The nucleolus-Guardian of cellular homeostasis and genome integrity. Chromosoma 2013, 122, 487-497. [CrossRef] [PubMed]

154. Ide, S.; Miyazaki, T.; Maki, H.; Kobayashi, T. Abundance of ribosomal RNA gene copies maintains genome integrity. Science 2010, 327, 693-696. [CrossRef] [PubMed]

155. Charlesworth, B.; Sniegowski, P.; Stephan, W. The evolutionary dynamics of repetitive DNA in eukaryotes. Nature 1994, 371, 215-220. [CrossRef] [PubMed]

156. Federico, C.; Scavo, C.; Cantarella, C.D.; Motta, S.; Saccone, S.; Bernardi, G. Gene-rich and gene-poor chromosomal regions have different locations in the interphase nuclei of cold-blooded vertebrates. Chromosoma 2006, 115, 123-128. [CrossRef] [PubMed]

157. Kirubakaran, T.G.; Grove, H.; Kent, M.P.; Sandve, S.R.; Baranski, M.; Nome, T.; De Rosa, M.C.; Righino, B.; Johansen, T.; Otterå, H.; et al. Two adjacent inversions maintain genomic differentiation between migratory and stationary ecotypes of Atlantic cod. Mol. Ecol. 2016, 25, 2130-2143. [CrossRef] [PubMed]

158. Fujiwara, A.; Abe, S.; Yamaha, E.; Yamazaki, F.; Yoshida, M.C. Chromosomal localization and heterochromatin association of ribosomal RNA gene loci and silver-stained nucleolar organizer regions in salmonid fishes. Chromosome Res. Int. J. Mol. Supramol. Evol. Asp. Chromosome Biol. 1998, 6, 463-471. [CrossRef]

159. Costa, G.W.W.F.; Cioffi, M.B.; Bertollo, L.A.C.; Molina, W.F. Unusual dispersion of histone repeats on the whole chromosomal complement and their colocalization with ribosomal genes in Rachycentron canadum (Rachycentridae, Perciformes). Cytogenet. Genome Res. 2014, 144, 62-67. [CrossRef] [PubMed]

160. Costa, G.W.W.F.; Cioffi, M.B.; Bertollo, L.A.C.; Molina, W.F. The Evolutionary Dynamics of Ribosomal Genes, Histone H3 and Transposable Rex Elements in the Genome of Atlantic Snappers. J. Hered. 2016, 107, 173-180. [CrossRef] [PubMed]

161. Mehner, T.; Pohlmann, K.; Elkin, C.; Monaghan, M.T.; Nitz, B.; Freyhof, J. Genetic population structure of sympatric and allopatric populations of Baltic ciscoes (Coregonus albula complex, Teleostei, Coregonidae). BMC Evol. Biol. 2010, 10, 85. [CrossRef] [PubMed]

162. Kobayashi, T. Ribosomal RNA gene repeats, their stability and cellular senescence. Proc. Jpn. Acad. Ser. B Phys. Biol. Sci. 2014, 90, 119-129. [CrossRef] [PubMed]

163. Glazer, A.M.; Killingbeck, E.E.; Mitros, T.; Rokhsar, D.S.; Miller, C.T. Genome Assembly Improvement and Mapping Convergently Evolved Skeletal Traits in Sticklebacks with Genotyping-by-Sequencing. G3 2015, 5, 1463-1472. [CrossRef] [PubMed]

164. Chen, X.; Zhong, L.; Bian, C.; Xu, P.; Qiu, Y.; You, X.; Zhang, S.; Huang, Y.; Li, J.; Wang, M.; et al. High-quality genome assembly of channel catfish, Ictalurus punctatus. GigaScience 2016, 5. [CrossRef] [PubMed]

165. Liu, Z.; Liu, S.; Yao, J.; Bao, L.; Zhang, J.; Li, Y.; Jiang, C.; Sun, L.; Wang, R.; Zhang, Y.; et al. The channel catfish genome sequence provides insights into the evolution of scale formation in teleosts. Nat. Commun. 2016, 7, 11757. [CrossRef] [PubMed]

166. Liu, H.; Chen, C.; Gao, Z.; Min, J.; Gu, Y.; Jian, J.; Jiang, X.; Cai, H.; Ebersberger, I.; Xu, M.; et al. The draft genome of blunt snout bream (Megalobrama amblycephala) reveals the development of intermuscular bone and adaptation to herbivorous diet. GigaScience 2017, 6, 1-13. [CrossRef] [PubMed] 
167. Pan, H.; Yu, H.; Ravi, V.; Li, C.; Lee, A. P.; Lian, M.M.; Tay, B.-H.; Brenner, S.; Wang, J.; Yang, H.; et al. The genome of the largest bony fish, ocean sunfish (Mola mola), provides insights into its fast growth rate. GigaScience 2016, 5. [CrossRef] [PubMed]

168. Brawand, D.; Wagner, C.E.; Li, Y.I.; Malinsky, M.; Keller, I.; Fan, S.; Simakov, O.; Ng, A.Y.; Lim, Z.W.; Bezault, E.; et al. The genomic substrate for adaptive radiation in African cichlid fish. Nature 2014, 513, 375-381. [CrossRef] [PubMed]

169. Conte, M.A.; Gammerdinger, W.J.; Bartie, K.L.; Penman, D.J.; Kocher, T.D. A high quality assembly of the Nile Tilapia (Oreochromis niloticus) genome reveals the structure of two sex determination regions. BMC Genom. 2017, 18. [CrossRef] [PubMed]

170. Lien, S.; Koop, B.F.; Sandve, S.R.; Miller, J.R.; Kent, M.P.; Nome, T.; Hvidsten, T.R.; Leong, J.S.; Minkley, D.R.; Zimin, A.; et al. The Atlantic salmon genome provides insights into rediploidization. Nature 2016, 533, 200-205. [CrossRef] [PubMed]

(C) 2018 by the authors. Licensee MDPI, Basel, Switzerland. This article is an open access article distributed under the terms and conditions of the Creative Commons Attribution (CC BY) license (http:/ / creativecommons.org/licenses/by/4.0/). 